\title{
Life cycle assessment and life cycle costing of an innovative component for refrigeration units
}

\author{
Jaume Gasia a, Claudia Fabiani b, c, Marta Chàfer ${ }^{\text {a, b }}$, Anna Laura Pisello b, c, \\ Agnese Manni ${ }^{\mathrm{d}}$, Maurizio Ascani ${ }^{\mathrm{d}}$, Luisa F. Cabeza ${ }^{\text {a, }}$ * \\ a GREiA Research Group, INSPIRES Research Centre, University of Lleida, Pere de Cabrera S/n, 25001, Lleida, Spain \\ ${ }^{b}$ CIRIAF - Interuniversity Research Centre, University of Perugia, Via G. Duranti 67, 06125, Perugia, Italy \\ ${ }^{\mathrm{c}}$ Department of Engineering, University of Perugia, Perugia, Italy \\ d Turboalgor S.r.l., Massa Martana, Perugia, Italy
}

\section{A R T I C L E I N F O}

\section{Article history:}

Received 27 June 2020

Received in revised form

27 January 2021

Accepted 16 February 2021

Available online 20 February 2021

Handling Editor: Dr Sandra Caeiro

\section{Keywords:}

Life cycle assessment (LCA)

Environmental impact

$\mathrm{ReCiPe}$

Life cycle costing (LCC)

Net present value (NPV)

Industrial refrigeration

\begin{abstract}
A B S T R A C T
Life cycle assessment (LCA) and life cycle costing (LCC) are innovative tools based on an innovative approach allowing to investigate the environmental and economic burdens of a product or service throughout its lifecycle. Although usually carried out individually, their integration in a comprehensive analysis could provide a substantial asset in every kind of decision-making procedures. In this study, the sustainability of a newly developed component for refrigeration units is investigated by applying these two tools in a cradle to grave approach in different scenarios. Results from the LCA show the huge impact associated with the manufacturing process of the kit compared to the transport. However, the use phase environmental analysis showed an environmental payback period always lower than 10 years. Results from the LCC show that the initial investment cost represents the highest share for the final user. Furthermore, favourable discounted payback periods are generally found, leading to net savings above $270,000 €$ in the case best-case scenario.
\end{abstract}

(C) 2021 Elsevier Ltd. All rights reserved.

\section{Introduction}

In recent years, climate change and resource depletion have become global concerns. The industrial sector, as one of the largest energy and resource consumer worldwide (Zhang et al., 2016), is asked to openly face these issues and achieve a suitable transition towards sustainability. In this context, about $17 \%$ of the global energy consumption is associated with steam compression refrigeration plants (Waide and Brunner, 2011). Improving the efficiency of such high energy-consuming equipment would significantly contribute to achieving better economic and environmental sustainability (Li and Tao, 2017).

A vapour compression refrigeration system generally consists of a closed circuit including a compressor, a condenser, an expansion device, an evaporator and the interconnecting pipes (Oh et al., 2016). Industrial refrigerators require high investment and

\footnotetext{
* Corresponding author.

E-mail address: luisaf.cabeza@udl.cat (L.F. Cabeza).
}

operating costs, and they are characterised by a long lifespan in which repairs and maintenances often occur (Brom et al., 2016). In view of its extended lifespan and of the huge consumption of energy and materials, the use phase of high energy-consuming equipment is particularly important for its sustainability assessment (Zhang et al., 2018). All this considered, a comprehensive approach focusing on both its economic and environmental sustainability is highly desirable and should be carried out concerning the perspectives of different stakeholders. In this context, life cycle assessment (LCA) and life cycle costing (LCC) represent powerful tools for developing an integrated evaluation with a focus on both these aspects, being able to provide valuable support in the decision-making procedure of producers and consumers of products and services.

LCA is an extensive analysis aimed at evaluating and quantifying the environmental impacts generated by a product or process throughout its life-cycle, usually from raw material extraction to final disposal (Visentin et al., 2019). As an acknowledged and flexible investigation technique, several examples of its application can be found on various industrial sectors from the production of 
innovative components and materials (Asdrubali et al., 2016; Klugmann-Radziemska and Kuczyńska-Łażewska, 2020; Lv et al., 2019), to the development of advanced manufacturing processes or energy systems (Auer et al., 2017; Ristimäki et al., 2013).

LCC can be defined as the assessment of all costs related to a product or service within its life cycle, from raw material extraction over production and use until disposal (Faraca et al., 2019; Hunkeler et al., 2008). Such economic technique has a long tradition in the industry, particularly in case of long lifetime and/or high maintenance, use or disposal costs. An LCC can be carried out, separating the analysis among different stakeholders (mainly producers and purchasers) (De Menna et al., 2018). The former uses LCC as a way to demonstrate that more effort for the production "pays off", by reducing the use, maintenance and disposal costs. The latter, on the other hand, makes use of it to take into account the costs that will be faced during the lifespan of the product, which depending on the application, can be much bigger than the simple purchase cost.

Currently, no comprehensive standards exist for LCC of products and/or services, except the ISO 15686-5 standard for buildings and constructed assets (ISO 15686-5, 2017). However, this comprehensive approach is becoming important for quantifying the economic feasibility of a project. Based on the LCC technique various design alternatives can be compared by projecting (discounting or compounding) all initial and incremental associated costs over the economic life of the project, also called the Life Cycle Period, to a common period of time. All these costs are analysed and quantified by specifically taking into account money discount rates and several economic parameters allowing to predict the long term evolution of the market, and refer all the costs that will occur during the lifetime of the investigated case study, to the present.

LCA and LCC studies are often carried out individually. However, their combination allows a holistic evaluation of the main environmental and economic characteristics of a product or system, which provides a substantial asset in every kind of decision-making procedures (Zhang et al., 2016). This is particularly true in the case of refrigerators, whose environmental burdens in the use phase are relatively significant if compared to those for manufacture (Baxter, 2019; Xiao et al., 2015).

In this study, LCA and LCC analysis are implemented to evaluate the sustainability of a newly developed component for refrigeration systems: the Turboalgor kit ${ }^{\circledR}$ (Ascani, 2012). This kit consists of an energy recovery heat exchanger and a turbocharger whose main purpose is optimising the functioning of the compressor unit. Once coupled into a conventional refrigeration plant, the Turboalgor kit ${ }^{\circledR}$ can 'increase energy savings and reduce cooling power. It is a disruptive solution to improve energy efficiency both for old and new refrigeration systems by transferring a highly efficient automotive technology to enhance energy recovery of heat exchangers. It was developed within the framework of the European directives of sustainable cities for reducing $\mathrm{CO}_{2}$ emissions and greenhouse gases, as well as creating lower impacts on the ecosystem, human health and resources.

The present study focuses on the evaluation of the environmental and economic impacts associated to the Turboalgor kit ${ }^{\circledR}$ throughout its entire life cycle. The present paper is organised as follows. In Section 2, the applied methods are introduced, and the case study presented. Sections 3 and 4 show the results from the LCA and the LCC analysis and discusses potential generalisation, uncertainties and sensitivity of the present study. Finally, Section 5 presents the main conclusions of the study and gives an outlook on future work.

\section{Methodology}

The aim of this study was to assess the potential environmental and economic benefits deriving from the introduction of an innovative optimisation kit (the Turboalgor kit ${ }^{\circledR}$ ) in a new or an existing refrigeration unit with the following characteristics:

- Electric power absorbed by the main compressor in the range $20 \div 300 \mathrm{~kW}$;

- Reciprocating (piston), scroll or screw-type refrigeration compressor;

- HFC (Freon) synthetic organic refrigerant working fluid, type R404a or similar;

- Condensing temperature: $+35^{\circ} \mathrm{C} \div+45^{\circ} \mathrm{C}$;

- Evaporation temperature: $-45^{\circ} \mathrm{C} \div+5^{\circ} \mathrm{C}$.

To this aim, the minimum, maximum and most common electrical consumption configurations of the coupled compressor were selected, i.e. $20 \mathrm{~kW}, 300 \mathrm{~kW}$, and $100 \mathrm{~kW}$, and the effect of the introduction of Turboalgor kit ${ }^{\circledR}$ was investigated in terms of environmental and economic parameters, based on LCA and LCC analysis (Table 1). It should be noted that the kit is always the same, regardless of the main compressor configuration and that it is simply introduced in the refrigeration system (see Fig. 1).

Each of the three selected configurations was investigated in two different scenarios (see Table 2):

- Best-Case (BC), corresponding to a system with an operating temperature of about $-25{ }^{\circ} \mathrm{C}$ (Low Temperature: LT) in which the integration of the kit in the refrigeration unit allows to obtain a $23 \%$ energy savings throughout the year;

- Worst-Case (WC), corresponding to a system with an operating temperature of about $+5{ }^{\circ} \mathrm{C}$ (High Temperature: HT) in which the integration of the kit in the refrigeration unit allows to obtain a $5 \%$ energy savings throughout the year.

The reported energy savings in the above were calculated by comparing the efficiency of several types of refrigeration systems before installing the Turboalgor kit, with the overall efficiency obtained from the same systems following the integration with the innovative device.

\subsection{Life cycle assessment (LCA)}

LCA allows the assessment of all environmental aspects and their consequent impacts throughout the life cycle of a product, from raw material extraction to disposal, identifying and quantifying the energy and material consumptions, as well as, the generated wastes (Guinée et al., 2011). Hence, the LCA helps to evaluate and identifying the most suitable alternatives to optimise or enhance the environmental impact of new and already designed products and processes (Ekvall et al., 2009; Rebitzer et al., 2004). It provides quantitative information, either on points of impact or kilograms of $\mathrm{CO}_{2}$ emitted in the atmosphere, of the analysed product, system or process at each stage (Bruijn et al., 2002). The methodology for any LCA is carried out in four different stages: definition of the object and scope of the study, inventory, impact assessment, and interpretation (Rebitzer et al., 2004).

\subsubsection{Goal and scope definition}

The objective of the LCA study was to quantitatively assess the environmental benefits derived from the integration of the Turboalgor kit ${ }^{\circledR}$ on conventional refrigeration units compared to the same predecessor system without the kit in terms of ecological and economic parameters. The above kit is a unique system that can be easily integrated into most kinds of refrigeration units, e.g. reciprocating (piston) and scroll or screw-type refrigeration compressors in the power range $20 \div 300 \mathrm{~kW}$. The LCA investigation was 
Table 1

Different scenarios assessed.

\begin{tabular}{|c|c|c|c|}
\hline Scenario & Refrigeration unit compressor power & Refrigeration unit compressor power & Refrigeration unit compressor power \\
\hline Best-Case - BC (LT = 23\% energy savings) & $20 \mathrm{~kW}$ & $100 \mathrm{~kW}$ & $300 \mathrm{~kW}$ \\
\hline Worst-Case - WC (HT $=5 \%$ energy savings) & $20 \mathrm{~kW}$ & $100 \mathrm{~kW}$ & $300 \mathrm{~kW}$ \\
\hline
\end{tabular}

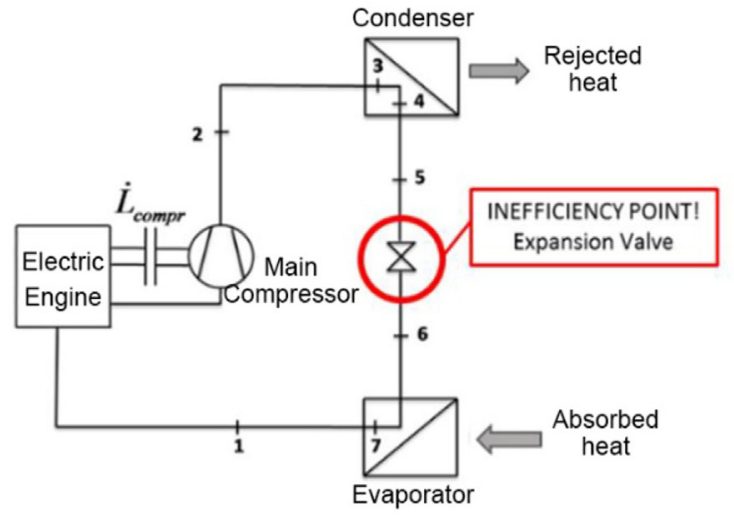

(a)

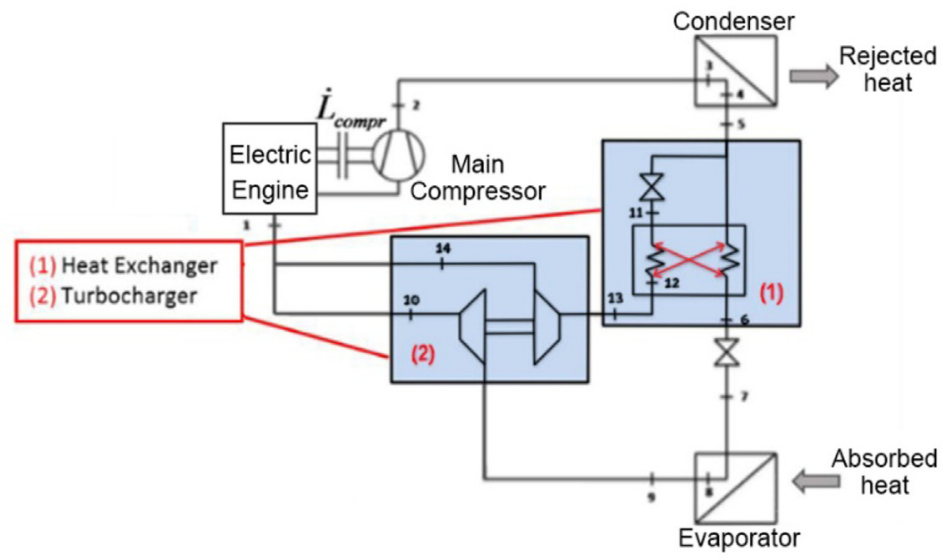

(b)

Fig. 1. (a) Conventional refrigeration system compared to (b) refrigeration system equipped with the Turboalgor kit ${ }^{\circledR}$, schematic view.

Table 2

Volume scenario of Turboalgor kit ${ }^{\circledR}$ sales considered by Angelantoni-Turboalgor SRL.

\begin{tabular}{llllll}
\hline Operating Temperatures & Country & 2019 & 2020 & 2021 & 2022 \\
\hline HT $\left(-25{ }^{\circ} \mathbf{C}\right)$ & Italy & 59 & 94 & 122 & 135 \\
& Germany & 69 & 110 & 143 & 159 \\
& France & 37 & 51 & 64 & 83 \\
& Spain & 45 & 73 & 94 & 105 \\
& UK & 60 & 95 & 124 & 137 \\
& Other & 0 & 45 & 73 & 94 \\
& Total & $\mathbf{2 7 0}$ & $\mathbf{4 6 8}$ & $\mathbf{6 2 0}$ & $\mathbf{7 1 4}$ \\
$\mathbf{L T}\left(\mathbf{5}^{\circ} \mathbf{C}\right)$ & Italy & 56 & 204 & 272 & 313 \\
& Germany & 65 & 230 & 307 & 353 \\
& France & 35 & 106 & 137 & 179 \\
& Spain & 45 & 174 & 232 & 267 \\
& UK & 59 & 230 & 308 & 354 \\
& Other & 0 & 45 & 174 & 232 \\
& Total & $\mathbf{2 6 0}$ & $\mathbf{9 8 9}$ & $\mathbf{1 4 3 0}$ & $\mathbf{1 6 9 7}$ \\
\hline
\end{tabular}

aimed at firstly quantifying the environmental burden of the kit as a whole and later defining the long term impacts of the coupled system (refrigeration unit + Turboalgor kit ${ }^{\circledR}$ ) as the difference between the burden of the kit and the obtained environmental savings due to its integration. This is to be reasonable since the original refrigeration system is maintained during the functioning of the coupled configuration.

This analysis was based on the international standards ISO 14040 (ISO 14040, 2006) and 14044 (ISO 14044, 2006) and considered the whole life cycle, known as cradle-to-grave life cycle assessment, taking into account the raw material extraction, the production, the transport, the use and the end-of-life (Rebitzer et al., 2004). According to the manufacturer, a lifetime of 10 years was considered, although the results can be extrapolated over time.

The environmental impact was calculated following the methodology of the LCA with the ReCiPe end-point methodology (Goedkoop, 2008; Huijbregts et al., 2017), giving points of impact by subcategories, and IPCC 2013 GWP100a (Intergovernmental Panel on Climate Change, 2014), giving equivalent emissions of $\mathrm{CO}_{2}$ emitted into the atmosphere. Besides being able to compare different systems and scenarios, the results also provide valuable information to know which equipment or element has a more significant impact on the environment and thus, being able to redesign, modify and optimise the system towards a more sustainable system.

\subsubsection{Functional unit}

The selected functional unit in this study is the whole Turboalgor kit ${ }^{\circledR}$ (Fig. 2 and Fig. 3), which is considered to be used during 10 years. All components accounted for the performance of this LCA are detailed in the material breakdown shown in Fig. 3. A more detailed breakdown is shown in the Appendix. Data for the inventory and impact assessment in this work are expressed based on the functional unit.

\subsubsection{System boundaries}

As previously mentioned, the system studied in this LCA focuses on the full life cycle of the Turboalgor kit ${ }^{\circ}$, from the extraction of raw materials until the end-of-life management (Fig. 4). All energy and natural resources inputs are traced back to the extraction of resources, and wastes and emissions from each life cycle stage are quantified. Therefore, the following stages were included within the system boundaries:

- Raw material extraction.

- Raw material distribution to converters.

- Raw material transformation into semi-manufactured product.

- Semi-manufactured product distribution to final product producer.

- Final product production.

- Final product distribution to final users.

- Final product operation and maintenance.

- End-of-life management.

\subsubsection{Impact analysis}

The Ecoinvent v3.5 database (Wernet et al., 2016) was used to 


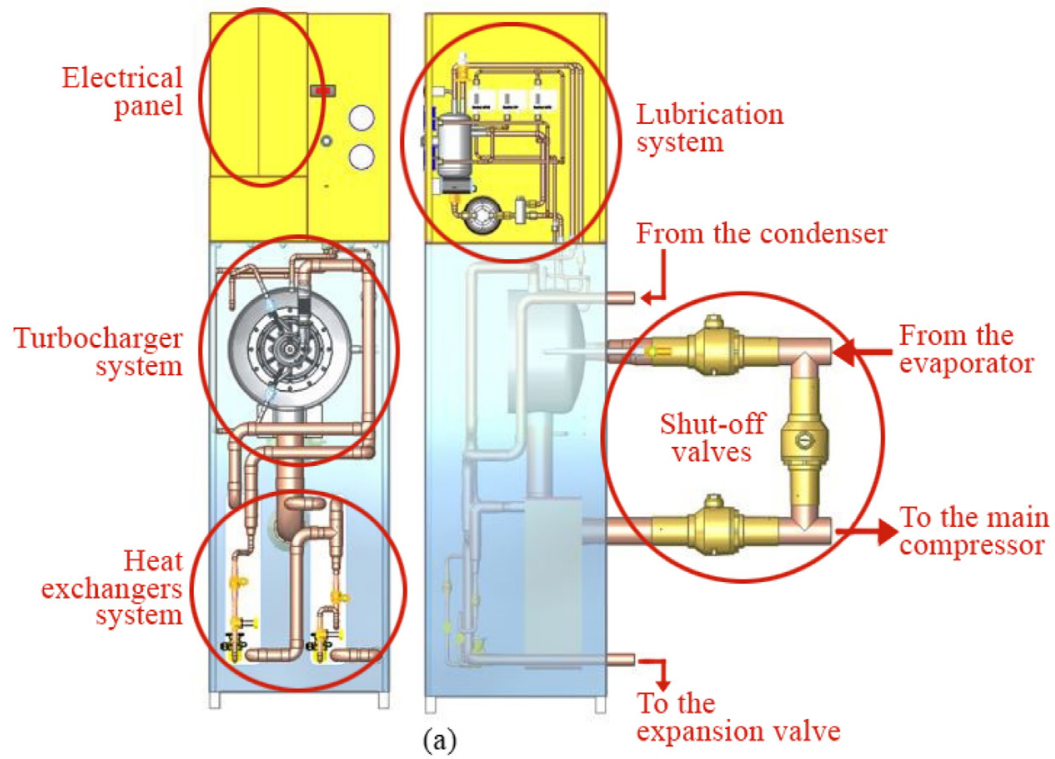

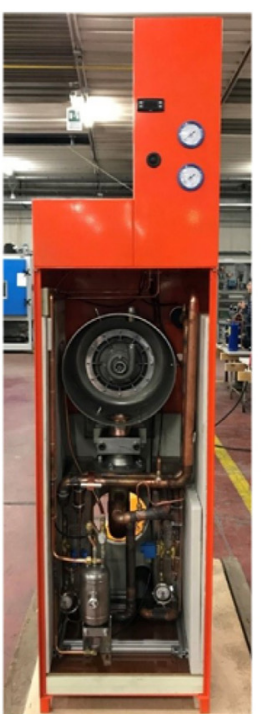

(b)

Fig. 2. Turboalgor kit®. (a) Schematic view and (b) real picture.

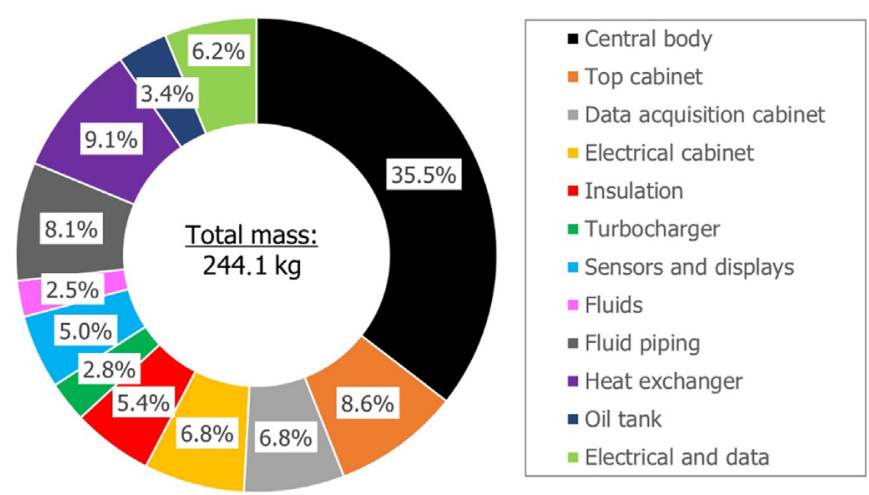

Fig. 3. Material breakdown of the Turboalgor kit ${ }^{\circledR}$.

obtain the environmental impacts associated with the materials, transport, and energy employed in the study. This database contains LCI data that are represented to a large extent on the level of direct inputs and outputs of unit processes (Frischknecht et al., 2005). This database is widely recognised for its integrity, usability, and dedicated resources (Martínez-Rocamora et al., 2016).

As mentioned above, the quantitative indicators used were the ReCiPe2016 and the IPCC2013 GWP. This IPCC 2013 Indicator is the Global Indicator proposed by the Intergovernmental Panel on Climate Change (IPCC), which quantify the climate change impacts of greenhouse gas emissions due to human activities by aggregating them into a common unit, e.g. $\mathrm{CO}_{2}$ equivalent (Intergovernmental Panel on Climate Change, 2014). On the other side, the adopted method, ReCiPe is the successor of EI99 and CMLIA (Goedkoop et al., 2013). The primary objective of the ReCiPe method is to transform the long list of life cycle inventory results, into a limited number of indicator scores (Huijbregts et al., 2017) in order to facilitate the interpretation of the results.

ReCiPe2016 provides a state-of-the-art method to convert life cycle inventories to a limited number of life cycle impact scores on midpoint and endpoint level. Three endpoint categories (human health, ecosystem quality, and resource scarcity) and 17 midpoint categories were included with a focus on providing characterisation factors that are representative on the global scale in line with the global nature of many product life cycles (Huijbregts et al., 2017). The impacts can be assessed with the help of the mid-point or endpoint model. Mid-point impact or problem-oriented model interprets impacts by environmental issues such as abiotic depletion and climate change. The Endpoint or damage-oriented model interprets impacts to the human health, natural environment, and natural resources (Dong and $\mathrm{Ng}, 2014$ ).

\subsubsection{Data inventory}

The life cycle inventory (LCI) analysis is the phase of life cycle assessment involving the compilation and quantification of inputs and outputs for a product throughout its life cycle. In the present study, inventories of significant environmental flows to and from the environment, and internal material and energy flows, were produced. Also, at this point, potential replacements must be taken into account, according to the useful life of each component, and maintenance of the final product during the operation stage.

The production of raw materials used afterwards for the different parts of the kit, such as the different metals, polymers, liquids, and others was included in the study (Fig. 3). Moreover, the transport from the raw material producer to converters was evaluated together with the extraction due to the lack of information. In this stage, the following assumptions were made:

- According to the type of raw materials:

o Steel: All type of steel is treated as "chromium steel 18/8".

o Aluminium: All type of aluminium is treated as "regular aluminium".

o Glass: All type of glasses is treated as "flat glass, uncoated".

o Ceramic: All type of ceramics is treated as "refractory production, basic, packed".

o Plastics: depending on the plastic characteristics given by the suppliers, they are treated differently. The different options evaluated are "polyethylene, high density, granulate", "polyurethane, rigid foam", "polyethylene terephthalate, granulate, bottle grade", "seal, natural rubber based".

o Copper: All type of coppers is treated as "regular copper".

o Brass: All type of brasses is treated as "regular brass".

o Refrigerant is assumed R134a. 


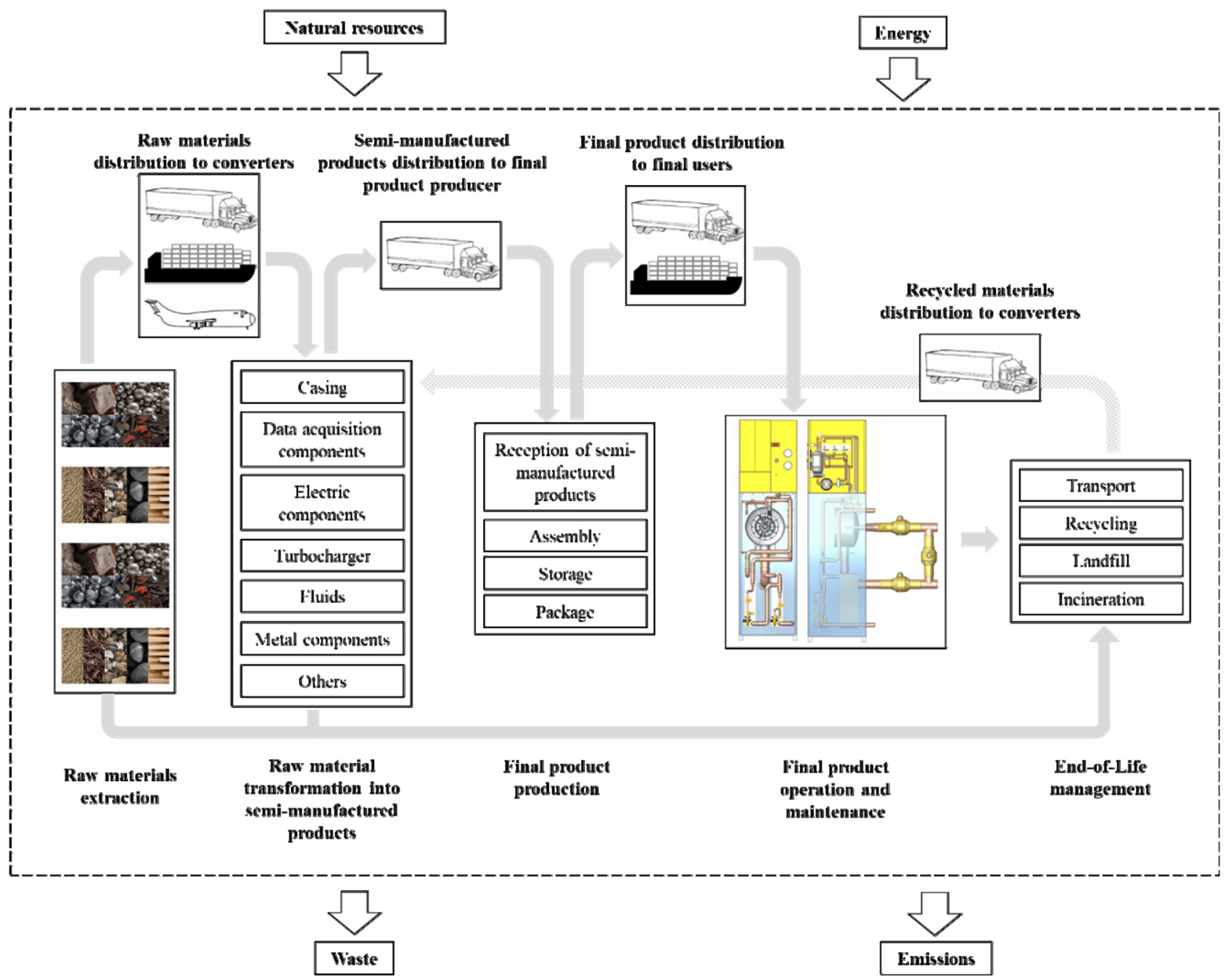

Fig. 4. Life cycle assessment system boundary of Turboalgor kit $\circledast$.

The transformation (machining) of the different raw material into the different semi-manufactured products which compose the Turboalgor kit ${ }^{\circledR}$ was also evaluated together with the distribution of the semi-manufactured product to the final product producer for an analogous reason. This includes the production of the different components shown in Fig. 3, as well as the production of the different subcomponents included within these components but not shown in the figure.

In this stage, there were some transformation processes which were ambiguous or not available in the database used for the analysis. Therefore, the following assumptions were made:

- The process to produce plastic pieces is assumed to be always "injection moulding".

- There is no stamping process in the database, so this process is assumed to be "deep drawing, steel, $650 \mathrm{kN}$ press, automode".

- There is no moulding process for steel in the database, so this process is assumed to be "deep drawing, steel, $650 \mathrm{kN}$ press, automode".

- There is no moulding process for aluminium in the database, so this process is assumed to be "impact extrusion of aluminium, deformation stroke".

- There is no wire drawing for lead and platinum in the database, so this process is assumed to be "Wire drawing, steel".
- The process to produce HEX nuts is assumed to be the same way than the one for the screws.

- The oil level sensor, the oil tank thermostat display, and the pressure display are not on the database as components, so it is assumed to be "market for an integrated circuit, logic type".

- The energy use of production and infrastructure for factory for the lubricant recirculation pump is not considered.

- There is no fuse, circuit breaker, trigger, and relay in the database, so they are treated as a connector.

- There is no integrated filter, multifunctional timer, energy analyser, and amperometric transformer in the database, so they are treated as a power unit supply.

- The assembly of the different subcomponents of a metal component is assumed to be done by "welding, arc".

- If the component evaluated is not located in the database (i.e. temperature sensors), it is exploded into its different subcomponents and each one is evaluated according to the quantity and kind of material of which are composed.

- Stickers are not considered.

According to the transport of the semi-manufactured products to the final product producer, the present study was not able to define the specific distances of every single raw material analysed. Hence, the average distances and transport mediums given by the 
database that was used for the analyses were used.

The transport of the semi-manufactured product to the factory of the final product producer (Angelantoni-Turboalgor SRL), is based on assumptions. In particular, it was assumed that all the suppliers are located around an average distance of $200 \mathrm{~km}$ from the factory and that a small lorry (lorry 3.5-7.5 metric ton, EURO5) was used as a mean of transport.

The production of the final product that in the present case is the Turboalgor kit ${ }^{\circledR}$ contains the assembly and quality check, in the factory of Angelantoni-Turboalgor SRL in Massa Martana (Italy) of the different components that form the kit. In this stage, the following assumptions were made:

- The impact of workers is assumed to be negligible.

- The assembly process consumes $400 \mathrm{~W}$ of electricity while the quality check process consumes $200 \mathrm{~W}$ of electricity.

- The assembly process takes $16 \mathrm{~h}$ per functional unit while the quality check takes $4 \mathrm{~h}$ per functional unit.

- There is no water consumption in the warehouse.

The distribution of the final product to the final users was done according to the volume scenarios considered by AngelantoniTurboalgor SRL (Table 2). In the present study, it was not possible to make an accurate assessment of the proportion of the transport and distances that should be allocated to the functional unit, since the market study done by the company is a rough assumption according to its expectations. However, some assumptions were made in the present study on the exact location of the final user and distance from the Turboalgor kit ${ }^{\circledR}$ producer and type of transportation, in order to calculate the impact of this stage (Table 3 ).

The operation of the final product is one of the most important stages of the LCA since it could strongly affect the overall outcome of the study, depending on the different consumptions of energy and its energy source (Chàfer et al., 2019). Hence, this study considered that the Turboalgor kit ${ }^{\circ}$ consumes $231 \mathrm{~W}$ due to the different electrical subcomponents (Table 4). This data was obtained from the technical data sheets of each component. The useful life of the kit is 10 years according to the manufacturer with an average operation time per year of $4000 \mathrm{~h}$. Moreover, according to the technical representatives of Angelantoni-Turboalgor SRL no maintenance is needed in the Turboalgor kit ${ }^{\circledR}$ during the 10 years of useful life.

In the present study, recycling is considered and, if possible, all components are treated as "collection for final disposal". The cases
Table 4

Electrical consumption of the Turboalgor kit ${ }^{\circledR}$ electrical consumer subcomponents.

\begin{tabular}{ll}
\hline Component & Consumption \\
\hline Pressure sensor & $3.20 \mathrm{~W}$ \\
Displays & $3.00 \mathrm{~W}$ \\
Lubrication magnetic drive oil pump & $100.00 \mathrm{~W}$ \\
Multifunctional timer & $0.60 \mathrm{~W}$ \\
Green LED & $0.08 \mathrm{~W}$ \\
Power supply unit & $120.00 \mathrm{~W}$ \\
PLC Smart Module & $0.84 \mathrm{~W}$ \\
Energy analyser & $2.50 \mathrm{~W}$ \\
Data acquisition module & $0.84 \mathrm{~W}$ \\
Total & $\mathbf{2 3 1 . 0 6} \mathbf{~ W}$ \\
\hline
\end{tabular}

which are not treated like this, are specified below:

- Aluminium: "sanitary landfill" since final disposal is not in the database.

- Copper: "treatment of copper scrap by electrolytic refining".

- Lubricant and refrigerant: "market for waste mineral oil".

- There is no disposal for rock wool in the database, so it is assumed to be "treatment of waste polyethene/polypropylene product, collection for final disposal".

- There is no disposal for ceramic in the database, so it is assumed to be "treatment of waste brick, collection for final disposal".

- There is no disposal for lead and platinum in the database, so it is assumed to be "Treatment of waste reinforcement steel, collection for final disposal".

- There is no disposal for brass in the database, so it is assumed to be "treatment of copper scrap by electrolytic refining".

- There is no disposal for the oil filter in the database, so it is assumed to be "treatment of waste paperboard, sanitary landfill".

- There is no disposal for power supply unit, so it is assumed to be "treatment of used desktop computer, manual dismantling".

- The warehouse where the final TC assembly is done is assumed to remain after the lifetime of the products.

\subsubsection{Limitations}

The main limitation of this study, such as in similar LCAs, is the difficulty of finding accurate and reliable data to be used in the life cycle inventory, especially concerning complex materials and products, from external producers. Lack of information through the supply chain concerning the product has made it unfeasible to

Table 3

Assumptions done in the final product distribution to final users.

\begin{tabular}{|c|c|c|c|c|}
\hline \multirow[t]{2}{*}{ Case } & \multicolumn{3}{|l|}{ Destination } & \multirow[t]{2}{*}{ Mean of transport } \\
\hline & Country & Route & Distance & \\
\hline 1 & Italy & $\begin{array}{l}\text { Massa Martana - } \\
\text { Naples }\end{array}$ & 320 km & Middle lorry (lorry $7.5-16$ metric ton, EURO5) \\
\hline 2 & Germany & $\begin{array}{l}\text { Massa Martana - } \\
\text { Frankfurt }\end{array}$ & $1200 \mathrm{~km}$ & Middle lorry (lorry $7.5-16$ metric ton, EURO5) \\
\hline 3 & France & $\begin{array}{l}\text { Massa Martana - } \\
\text { Marseille }\end{array}$ & $850 \mathrm{~km}$ & Middle lorry (lorry $7.5-16$ metric ton, EURO5) \\
\hline 4 & Spain & $\begin{array}{l}\text { Massa Martana - } \\
\text { Madrid }\end{array}$ & $1900 \mathrm{~km}$ & Middle lorry (lorry $7.5-16$ metric ton, EURO5) \\
\hline 5 & UK & $\begin{array}{l}\text { Massa Martana - } \\
\text { London }\end{array}$ & $1800 \mathrm{~km}$ & Middle lorry (lorry $7.5-16$ metric ton, EURO5) \\
\hline \multirow[t]{3}{*}{6} & Others (USA) & $\begin{array}{l}\text { Massa Martana - } \\
\text { Port of Civitavecchia }\end{array}$ & $140 \mathrm{~km}$ & Middle lorry (lorry 7.5-16 metric ton, EURO5) \\
\hline & & $\begin{array}{l}\text { Port of Civitavecchia - } \\
\text { Port of New Jersey }\end{array}$ & $7570 \mathrm{~km}$ & Transoceanic ship \\
\hline & & $\begin{array}{l}\text { Port of New Jersey - } \\
\text { Random city within the selected distance }\end{array}$ & $2000 \mathrm{~km}$ & Middle lorry (lorry $7.5-16$ metric ton, EURO5) \\
\hline
\end{tabular}


obtain the materials' breakdown.

\subsection{Life cycle costing (LCC)}

An LCC is a comprehensive decision-making tool that can be used for evaluating the total costs generated over the entire lifetime of a product or service. By comparing different alternatives, an LCC allows to identify the potential cost drivers as well as the cost savings of a product or service and determine the most competitive configuration. The LCC analysis carried out in this work focuses on the entire life cycle (cradle-to-grave) of the Turboalgor kit ${ }^{\circledR}$. However, in this case, the product buyer was selected as the main life cycle actor. For this reason, all the expenses that are associated with the product development and production are quantified in the initial investment and installation cost faced by the life cycle actor. The selection of the product buyer as the main life cycle actor of the LCC study derives from the consideration that for high energy consuming appliances such as industrial refrigerators, the economic and environmental burdens from the use-phase are significant compared to those of manufacture (Xiao et al., 2015). The LCC, consisting of capital (CAPEX) and operational expeditures (OPEX), was derived by using a cost breakdown structure (CBS) over a given study period, and all costs were adjusted (discounted) to properly reflect the time-value of money. The LCC methodology followed in this work is based on the present-value method outlined in the NIST Handbook 135 for the Federal Energy Management Program (Fuller and Petersen, 1996).

Also, in this case, a lifetime of 10 years (time zero is referred to January 1st, 2019) and 4000 working hours were considered for the system, i.e. $50 \%$ of the actual duty cycle. The analysis allowed to compare the Turboalgor kit ${ }^{\circledR}$ when applied to three different refrigeration systems i.e. characterised by 20,100 and $300 \mathrm{~kW}$ power of the main compressor in the refrigeration unit. Furthermore, as previously discussed in Section 2, two different scenarios, i.e. BC (Best-Case) and WC (Worst-Case) were assessed. The LCC was carried out considering the same functional unit and system boundary of the LCA study.

\subsubsection{LCC inventory and evaluation method}

Following the approach proposed in the Life-cycle costing manual for the Federal energy Management Program (Fuller and Petersen, 1996), the cost items taken into account in this work are classified by the following categories:

- Investment costs $\left(\mathrm{C}_{\mathrm{I}}\right)$, which equals to the sum of the Turboalgor kit ${ }^{\circledR}$ cost, and the cost of its installation.

- Periodical maintenance costs $\left(C_{M}\right)$, which mainly consists of the oil changes directly carried out by the user, since following the producer's inputs, no additional maintenance is taken into account in this study.

- Operational costs $\left(C_{0}\right)$, that are the electric energy costs of a refrigeration unit with and without the Turboalgor kit $₫$, depending on the selected scenario.

- Residual value $\left(\mathrm{C}_{\mathrm{EOL}}\right)$, defined as the remaining value at the end of the study period, in this case it consists of the end-of-life disposal costs of the goods.

All these costs contribute to the determination of the global cost and the LCC is calculated as the present value (PV) of the different costs.

The general formula for the LCC calculation is the following Eq. $(1)$ :
$L C C=\sum_{t=0}^{N}\left(\frac{C_{t}}{(1+d)^{t}}\right)$

Where $L C C$ is the life cycle cost; $C_{t}$ is the sum of the relevant costs during a single period $\mathrm{t}$ and it includes initial and future costs; $d$ is the discount rate or return that could be earned in alternative investments; and $t$ is the number of time periods.

Considering the buyer as the main life cycle actor, the investment costs $\left(C_{i}\right)$ can be defined as the sum of:

o The Turboalgor kit ${ }^{\circledR}$ purchase cost.

o Purchase cost for the control and management software that regulates the functioning of the kit.

o The installation cost of the Turboalgor kit ${ }^{\circledR}$ which, according to the producers is always quantified in the amount of $4500 €$.

All these costs were here defined based on the specifications provided by the manufacturer commercial manager. They are faced at time zero in the life cycle, so they are already expressed in the present value (PV).

Maintenance cost $\left(C_{M}\right)$, are the expenses incurred to keep an item in good condition or good working order. When purchasing an item that requires upkeep consumers should consider the initial price tag as well as the item's ongoing maintenance expenses. Maintenance costs are divided in:

- Periodic ordinary maintenance costs $\left(C_{M}\right)$. Defined as $1 \%$ of the purchase cost, according to the producer of the Turboalgor kit ${ }^{\circledR}$. It is an annual cost that is subjected to the annual discount rate. Periodic ordinary maintenance costs are recurring uniform amounts faced during the entire life cycle of the product, so they are taken to the present value through the uniform present value (UPV) concept.

- Extraordinary maintenance and repair costs $\left(C_{R}\right)$. Defined as every maintenance out of the ordinary periodic one, it is not considered in this LCC.

Concerning operational costs $\left(\mathrm{C}_{0}\right)$, they are defined as the expenses which are related to the operation of the coupled refrigeration unit-Turboalgor kit ${ }^{\circledR}$ setup. In this LCC, the operational costs coincide with energy costs. As previously said, an average annual operating time of $4000 \mathrm{~h}$ was assumed for the refrigeration unit, against the real total operating hours' amount of $8000 \mathrm{~h}$, for safety reasons.

Operational costs, and specifically, energy costs are taken to the present value through the modified uniform present value (UPV*) factors that are classified as annually recurring non-fuel costs.

With reference to the disposal costs $\left(C_{E O L}\right)$, since no real data were available for the prototype, and following the inputs from the producers, a $1 \%$ of the product purchase cost was assumed in each configuration, based on the fact that it is mainly necessary to dispose of "standard" materials (aluminium, iron, plastic, etc.). Also, there are no hazardous fluids or materials to dispose of. In particular, the gas contained in the kit will be recovered according to the procedure described in the "Environmental risk assessment for activities involving the use of fluorinated gases" plan (statistica, 2019).

Since it is a one-time amount that needs to be paid at the end of the life cycle of the product, the residual value is transformed into present value by means of the single present value (SPV) factor calculated at years 10 . 


\subsubsection{Considered economic parameters}

The present LCC analysis was carried out according to the annualised method. In this methodology, all future costs are estimated based on year zero values, i.e. considered as the year of the expenditure.

Future rates of inflation and interest must be predicted and used for defining the net present value of all the costs faced by the user during the entire life cycle of the system. In particular, the following values, referred to average European values, are used to define the proper annualised value:

o Inflation rate $=1.31 \%$ (statistica, 2019).

o Real discount rate $=2.4 \%$ (The World Bank, 2019).

o Nominal labour cost increase $=2.6 \%$ (Eurostat, 2019a).

o Nominal escalation rate for electricity $=3 \%$ (Eurostat, 2019b).

o Electricity price $=0.1434 € / \mathrm{kWh}$ (Eurostat, 2019c).

Based on the previous parameters, all the conversion factors for the different costs were calculated, as depicted in Table 5.

\section{Results from the life cycle assessment}

This section aims at graphically presenting the main results of the LCA for the Turboalgor kit ${ }$. The different stages of the life cycle are globally (Section 3.1) and individually (from Section 3.2 to Section 3.4) analysed.

\subsection{Entire life cycle}

A detailed summary of the environmental impacts in each stage of the Turboalgor kit ${ }$ life cycle is shown in Fig. 5, for the GWP2013, and in Fig. 6, for the ReCiPe Endpoint. Notice that only the case of the final user in Italy is shown in this section for a better discussion of the results. However, the influence of the transport to the other final users as well as the operation and maintenance of the Turboalgor kit ${ }^{\circledR}$ in such final user countries, are discussed explicitly in the following sections, although they represent a small share in the life cycle environmental impact. Results showed that the stage with the highest impact to the environment is the cradle to gate, which contains the raw material extraction, the raw material distribution to converters, the raw material transformation into a semimanufactured product, and the semi-manufactured product distribution to final product producer. The reason lies in the fact that a large quantity of material and energy is consumed in this stage, which is translated to a higher quantity of emissions and impacts on the environment. The second stage with the highest impact on the environment is the assembly in the factory, which considers the impact of the warehouse and the electrical consumption for the assembly and quality check for one functional unit. Finally, the remaining three stages practically do not influence the environment if compared to the previous ones. Notice that in the final disposal stage, negatives values are observed due to the assumption done.

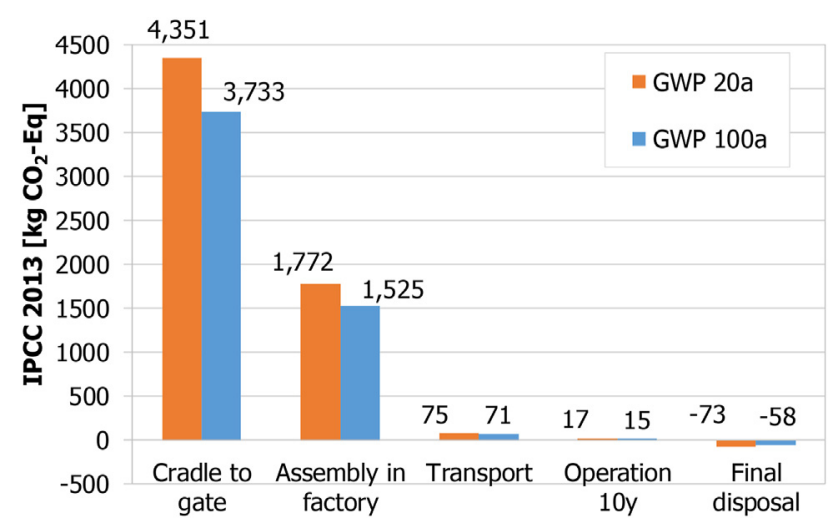

Fig. 5. Summary of the environmental impacts in each stage of the Turboalgor kit $\AA$ life cycle transported and used in Italy: IPCC 2013 Method.

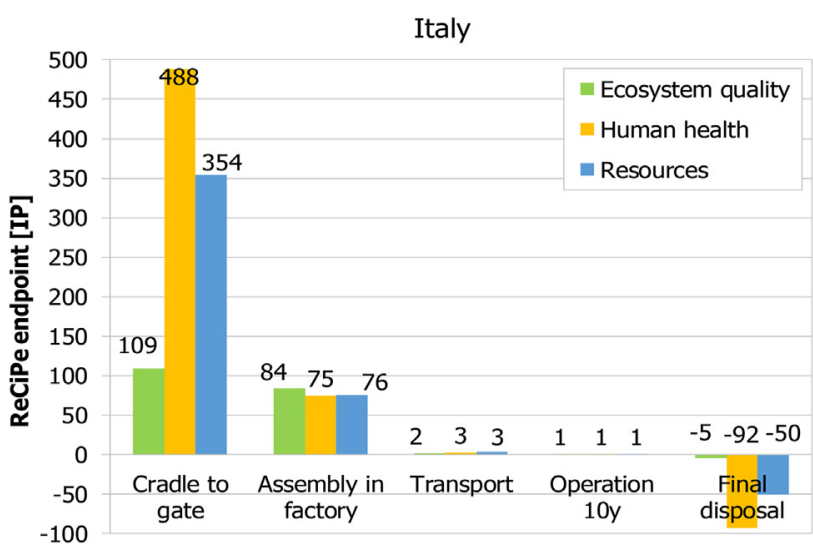

Fig. 6. Summary of the environmental impacts in each stage of the Turboalgor kit $\circledast$ life cycle transported and used in Italy: ReCiPe Endpoint Method.

Contribution from the impact categories to the single endpoint score is presented in Table 6. At the endpoint level, the damage to the ecosystem is breakdown into the categories where two impact categories are found to be the most influential which are climate change ecosystem with $46.39 \%$ of the total impact followed by the agricultural land occupation with $47.5 \%$. Regarding the damage to human health, the most influential category is human toxicity, with more than $50 \%$ of the total impact points. And finally, the two categories on resources (fossil depletion and metal depletion) have also a significant impact on each one. Human toxicity is so far the most contribution category, this is due to, as mentioned before a significant quantity of material (electric components) and energy is consumed in the abovementioned cradle to gate stage, which is translated to a higher quantity of emissions and impacts to the environment.

Table 5

Calculation scheme for the different investigated scenarios.

\begin{tabular}{|c|c|c|c|c|}
\hline $\begin{array}{l}\text { Cost item } \\
\text { (1) }\end{array}$ & Base Date Cost (2) & Year of occurrence (3) & $\begin{array}{l}\text { Discount factor } \\
\text { (4) }\end{array}$ & $\begin{array}{l}\text { Present value } \\
(5)=(2) \times(4)\end{array}$ \\
\hline $\begin{array}{l}\text { Initial investment cost } \\
\text { OM\&R } \\
\text { Electricity: } \\
20[\mathrm{~kW}] \times 4000[\mathrm{~h}] \text { at } 0.1434 € / \mathrm{h} \\
\text { Residual value }\end{array}$ & & $\begin{array}{l}\text { Base date } \\
\text { Annual } \\
\text { Annual } \\
10\end{array}$ & Already in & \\
\hline
\end{tabular}


Table 6

Contributions from impact categories toward endpoint single score.

\begin{tabular}{ll}
\hline Damage category & Impact points (i. p.) \\
\hline Ecosystem quality & \\
Terrestrial acidification & 0.24 \\
Terrestrial ecotoxicity & 0.44 \\
Agricultural land occupation & 88.3 \\
Freshwater eutrophication & 1.09 \\
Urban land occupation & 5.3 \\
Freshwater ecotoxicity & 0.56 \\
Natural land transformation & 3.93 \\
Marine ecotoxicity & 0.11 \\
Climate change, ecosystems & 90.35 \\
Total & 190.35 \\
Human Health & \\
Climate change, human health & 142.95 \\
Human toxicity & 244.43 \\
Photochemical oxidant formation & 1.06 \\
Ozone depletion & 0.23 \\
Particulate matter formation & 85.01 \\
Ionising radiation & 0.03 \\
Total & 473.74 \\
Resources & \\
Fossil depletion & 189.03 \\
Metal depletion & 194.26 \\
Total & 383.30 \\
\hline
\end{tabular}

\subsection{From raw materials extraction to final product producer (cradle} to gate)

As previously seen in Section 3.1, the stage with the highest impact to the environment is the cradle to gate. This section aims at presenting the impact of each one of the thirteen main components which form the Turboalgor kit ${ }^{\circledR}$, from the raw material extraction to the transport to the final product producer. The results are presented from the IPCC 2013 method (Fig. 7) and ReCiPe Endpoint method (Fig. 8) points of view.

Results showed, on the one hand, that the raw material

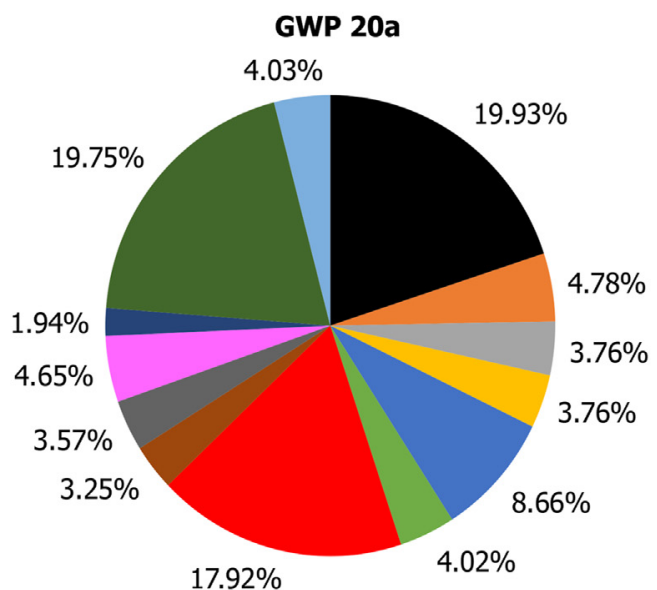

$\begin{array}{ll}\text { - Central body } & \text { Top cabinet } \\ \text { Electrical cabinet } & \text { Insulation } \\ \text { Sensors and displays } & \text { r Fluids } \\ \text { Heat exchanger } & \text { Oil tank } \\ \text { Packaging plastic } & \end{array}$

extraction, manufacturing and transport of the central body, all the components for the electricity and data, and the sensors and displays are responsible for more than the $50 \%$ of the greenhouse gases emissions of the Turboalgor kit $\AA$. The reason lies on the fact that the central body represents more than $1 / 3$ of the total weight of the kit. In contrast, the reason for the impact of the data and electrical components, sensors and displays is due to the materials which these components are made of (see Appendix). On the other hand, we can also see that, besides the previous components, the heat exchanger and the fluid piping, also have an important influence on the ecosystem quality, human health and resources (Fig. 8).

\subsection{Transport from the factory to the final user}

Up to the final product production stage, the location of the final user had no environmental impact, since the importance lied on the transport to the factory, which was the same for all cases. This section aims to show the impact of the location of the final user on the environment. However, it is worthy to be mentioned that, as shown in Figs. 5 and 6, the influence of the transport to the final users represents a small share in the life cycle environmental impact.

Results from the IPCC 2013 method (Fig. 9) and ReCiPe Endpoint method (Fig. 10) points of view show the influence of the distance, with higher impacts for higher distances. It can also be seen that there is not much difference between case 6 (USA) and the other cases, despite the distance difference is significant. The reason lies on the fact that the impact for the transport by transoceanic ship is much lower than the transport by lorry.

\subsection{Final product maintenance and operation}

Similarly, to the transport stage, the final product maintenance and operation stage practically has no influence on the entire life cycle because of its low energy consumption and the existence of no maintenance during the useful lifetime of the kit. The small

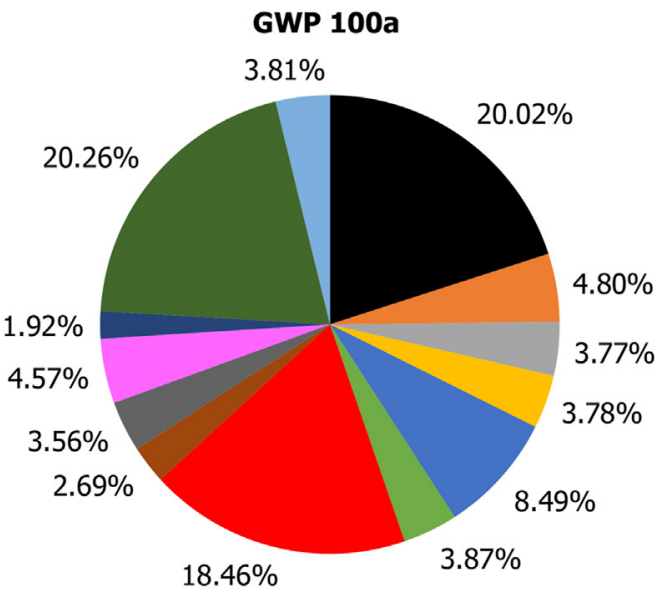

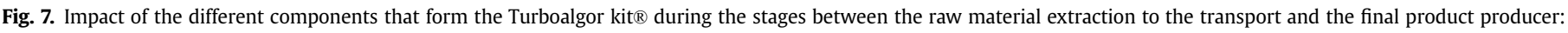
Method of IPCC 2013. 

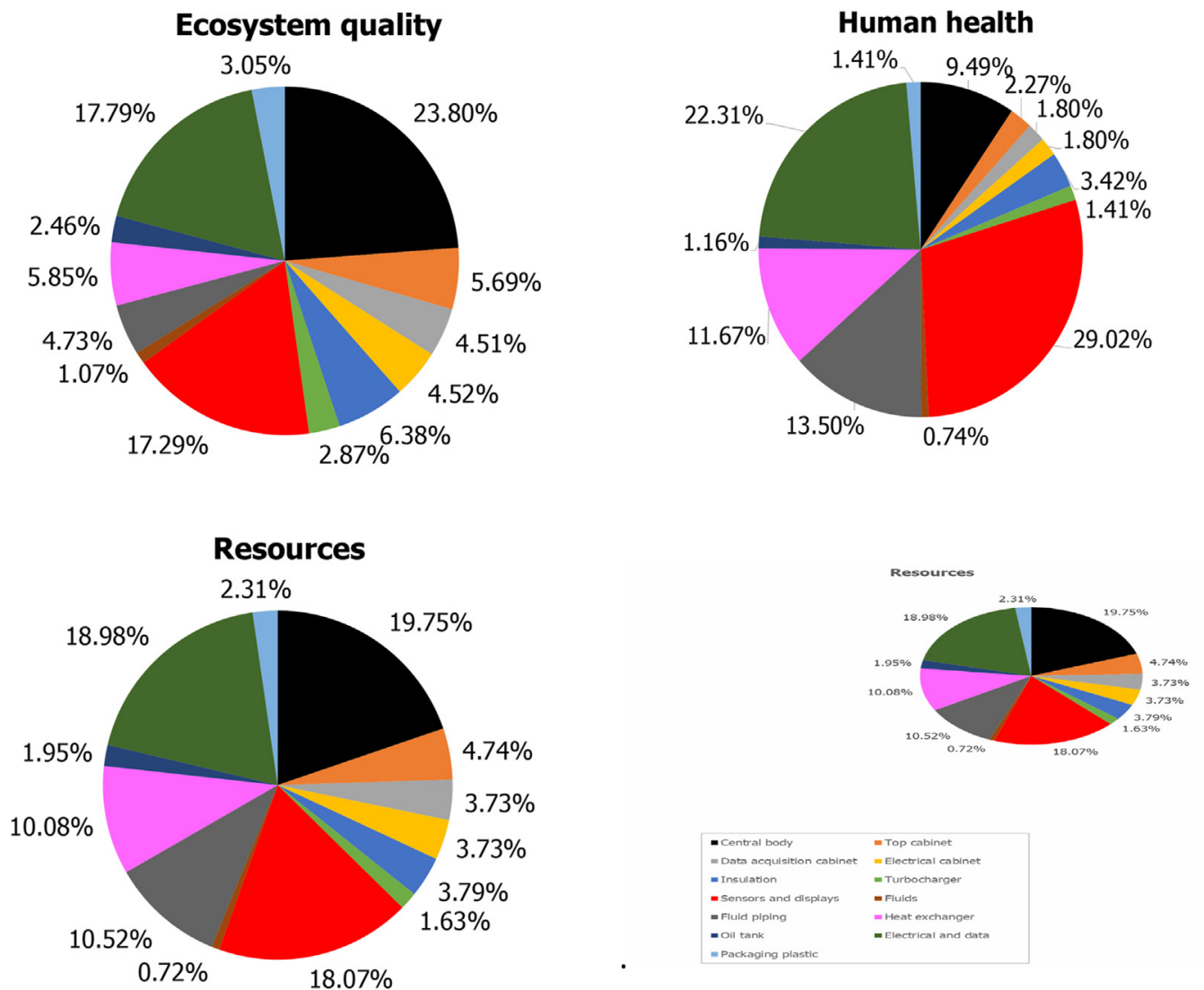

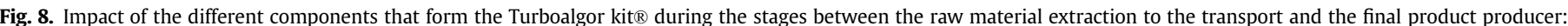
ReCiPe Method.

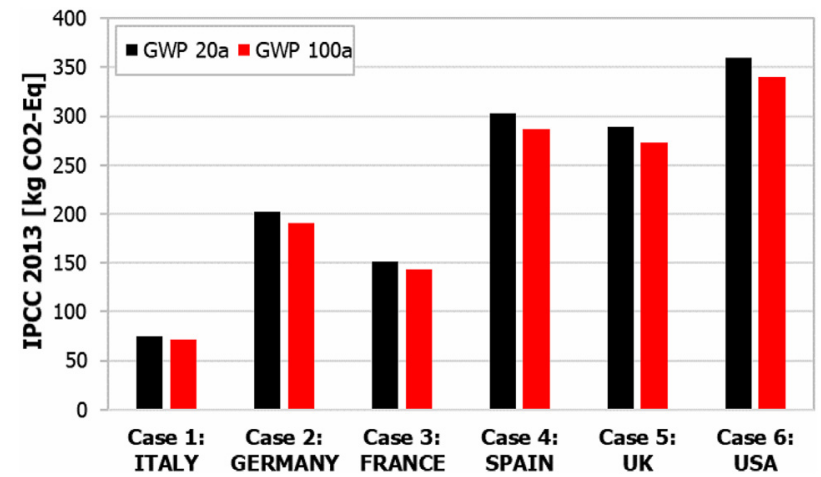

Fig. 9. Impact of the location of the final user during the transport of the Turboalgor

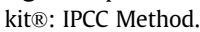

differences observed between the case studies (Fig. 11 and Fig. 12) are mainly due to the energy mix of each country.

\subsection{Environmental payback}

The environmental payback is the time, measured in years, required for the Turboalgor kit ${ }^{\circledR}$ to compensate for the environmental impact during the entire life cycle of the kit, as a result of the electrical energy savings on the refrigeration unit coupled to. Two main scenarios, i.e. BC and WC scenario (see Section 2), and three powers of the compressor unit, i.e. 20,100 , and $300 \mathrm{~kW}$, are evaluated for the case of Italy, assuming that the same kit evaluated in the present study can be indistinctly coupled to any refrigeration

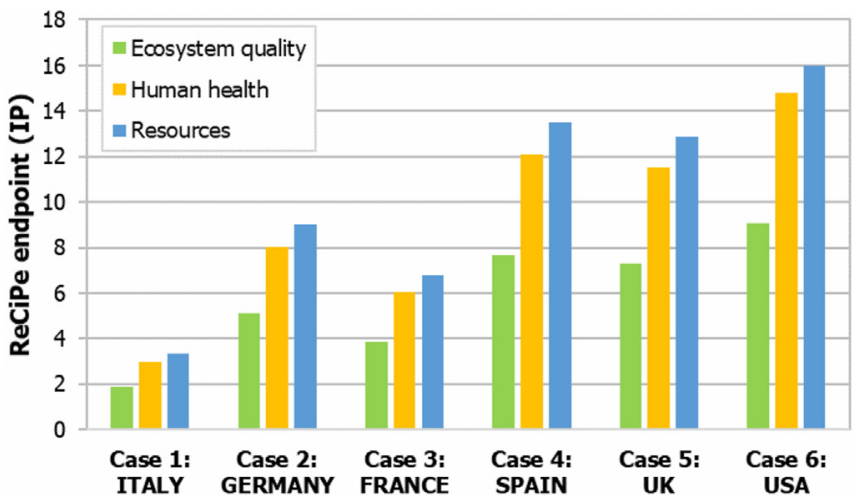

Fig. 10. Impact of the location of the final user during the transport of the Turboalgor kit®: ReCiPe Method.

unit.

Results from the study show that even for the WC scenario (Fig. 13) the environmental payback period is always lower than the 10 years of the kit useful life if the IPCC method is considered. In particular, the decrease of the environmental impacts associated to the electrical energy savings produced by the Turboalgor kit ${ }^{\circledR}$, allow compensating the environmental impacts due to the raw material extraction, transport, manufacturing, operation during ten years and end-of-life management, after 8 years and 4 months from the installation when a $20 \mathrm{~kW}$ unit is considered. Additionally, such environmental payback period is considerably lower when the $100 \mathrm{~kW}$ and $300 \mathrm{~kW}$ units are taken into account, less than 2 years 

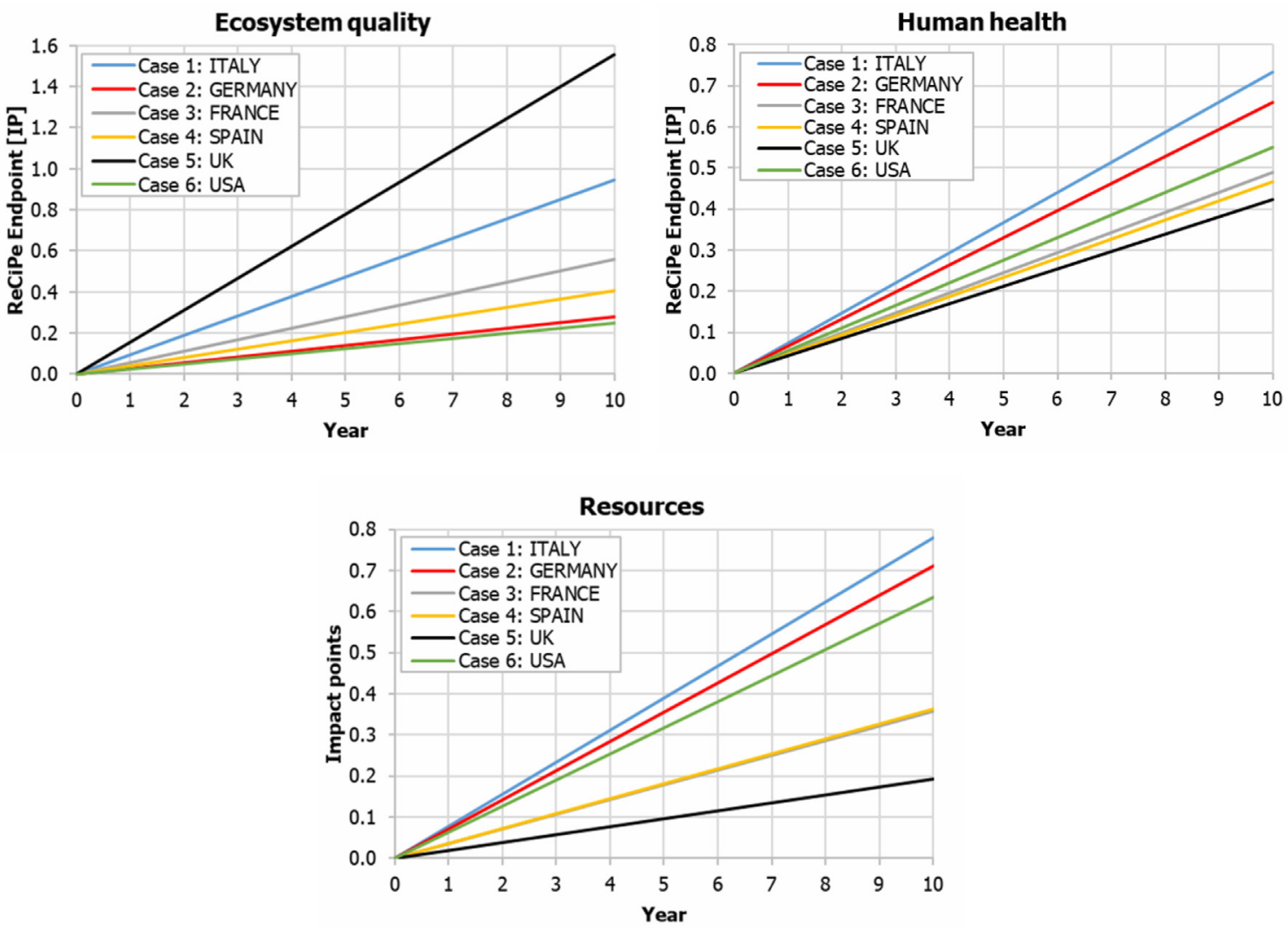

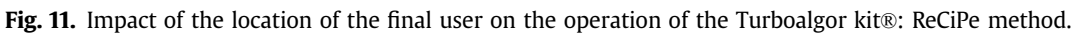

GWP 20a

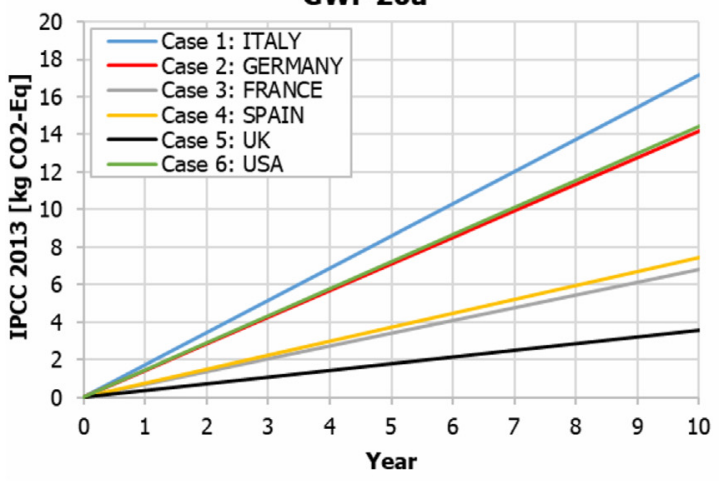

GWP 100a

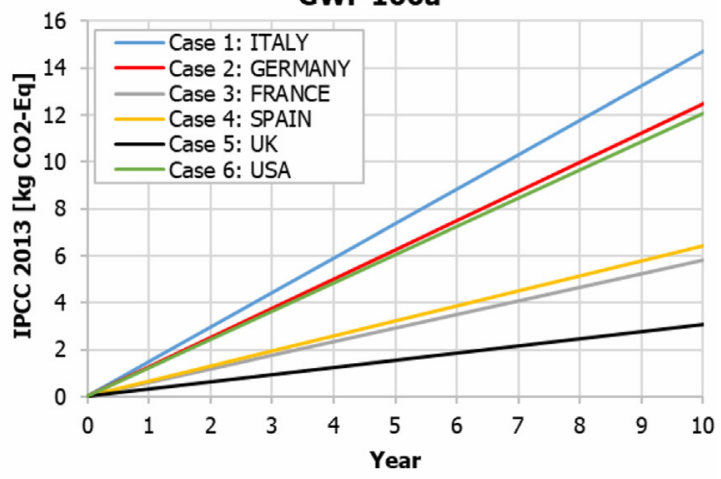

Fig. 12. Impact of the location of the final user on the operation of the Turboalgor kit $\mathbb{R}$ : IPCC method.

and 1 year, respectively. As for the ReCiPe method, in the WC scenario, the environmental payback period exceeds the 10 years of kit useful life for the human health and the resources category for the $20 \mathrm{~kW}$ refrigeration unit consumption, while it is always lower than 5 years in the other configurations.

Concerning BC scenario (Fig. 14) the environmental payback is always within the 10 years of operation for both the investigation methods taken into account, depending on the refrigeration unit electrical consumptions and the indicator studied. More in detail, the additional environmental impacts produced during the Turboalgor kit ${ }^{\circ}$ entire life cycle, are overcome within the fourth year of operation, and in some cases, i.e. in the case of the $20 \mathrm{~kW}$ unit, even within the first year.

\section{Results from the life cycle costing}

\subsection{Entire life cycle}

This section aims at presenting the main outcomes of the LCC for the Turboalgor kit ${ }^{\circledR}$. Results from the different scenarios are presented and compared, and the actual economic feasibility of the kit is investigated for the buyer stakeholder. Table 7 shows a summary of the LCC of the two considered scenarios for the Turboalgor kit $₫$ to be coupled to a 20,100 and $300 \mathrm{~kW}$ refrigeration unit. As can be seen from this table, both scenarios are always associated to the same energy costs: according to the producer, the electric consumption of the kit is the same for each application. The investment cost, always higher for the BC scenario, is at least $84.1 \%$ and never 


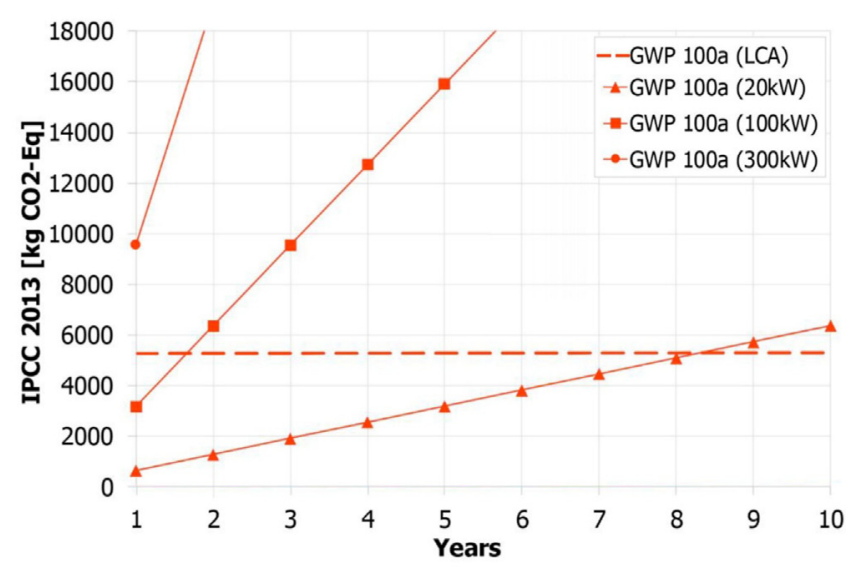

(a)

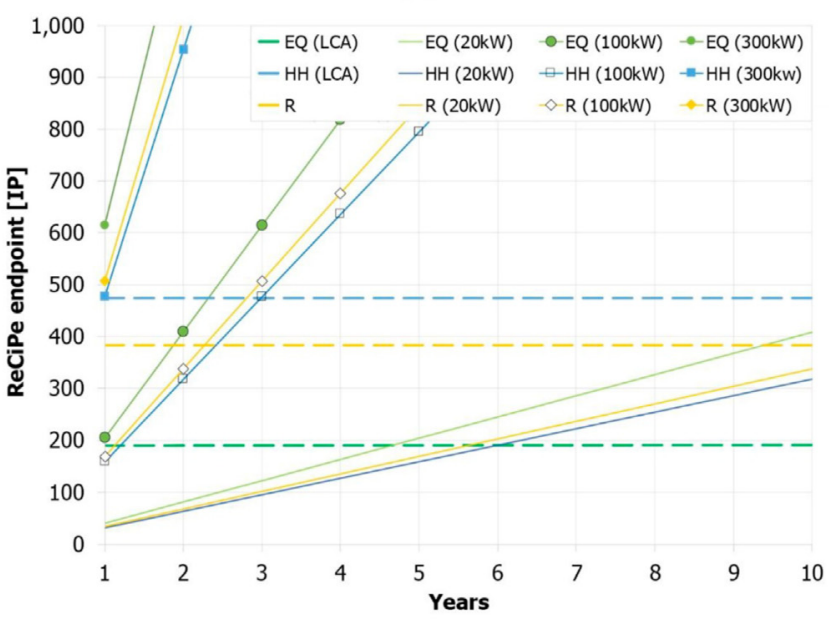

(b)

Fig. 13. Environmental payback of the Turboalgor kit ${ }^{\circledR}$ in Italy (WC scenario): (a) IPCC.; (b) ReCiPe. Note: EQ (energy quality), HH (Human health), R (Resources). The numerical values between parentheses mean the supposed power of the refrigeration unit coupled to the kit.

exceeds $89.1 \%$ of the final LCC value. Disposal and ordinary maintenance costs always represent a small share of the final life cycle cost. Globally, it can be stated that the Turboalgor kit ${ }^{\circledR}$ integrated to the $300 \mathrm{~kW}$ is the most impacting for the final user.

The integration of the kit in the refrigeration unit, however, produces different energy costs during the operational phase for the combined system. Indeed, as previously described in section 2 , both BC and WC scenario can reduce the energy consumption of a regular refrigeration system. This is all the more important if we consider that the share of these costs generally, represent the highest impact on the LCC of high energy consuming appliances such as industrial refrigerators (Xiao et al., 2015).

\subsection{Discounted payback period}

The economic payback period represents the time (in years) required for the Turboalgor kit ${ }^{\circledR}$ to compensate for the economic impact produced by the kit during its full life cycle, as a result of the electrical energy savings on the coupled refrigeration unit. In this work, we consider the discounted payback period (DPP) for taking into account the time value of money by discounting the cash flows for each period at a suitable discount rate.

By calculating this factor, it is possible to investigate the economic feasibility of the Turboalgor kit ${ }^{\circledR}$ integration in a real

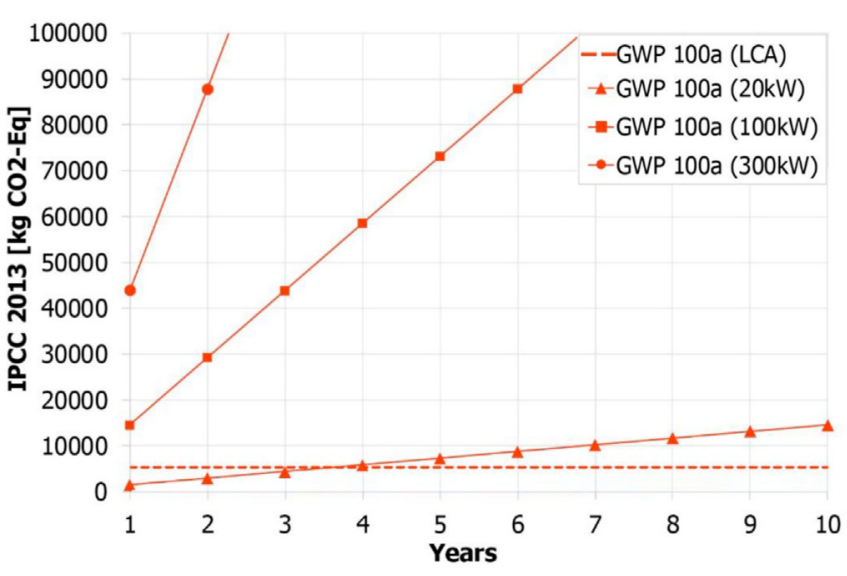

(a)

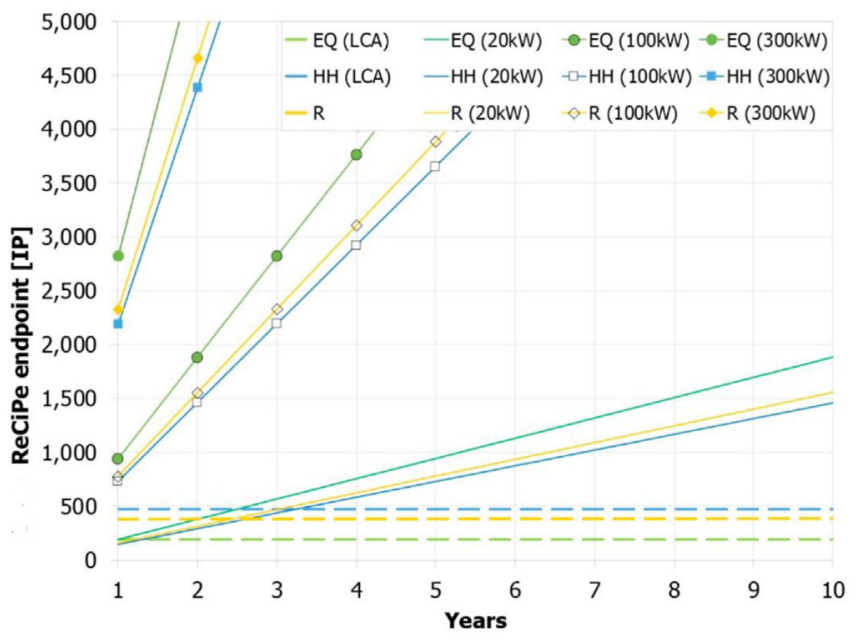

(b)

Fig. 14. Environmental payback of the Turboalgor kit® in Italy (BC scenario): (a) IPCC.; (b) Method. Note: EQ (energy quality), HH (Human health), R (Resources). The numerical values between parentheses mean the supposed power of the refrigeration unit coupled to the kit.

refrigeration system for the final user. For this purpose, the energy cost of the different refrigeration units is calculated for the selected time period (10 years), considering the same working time ( $4000 \mathrm{~h}$ per year), in terms of modified uniform present value through the UPV* factor, thus following the LCC approach. Later the energy saving produced by the integration of each Turboalgor kit ${ }^{\circledR}$ is calculated and the payback period of each scenario is defined considering the cumulated present value of the energy costs.

Fig. 15 shows the results from the calculation. As can be seen from this graph, in the BC scenarios, the Turboalgor kit ${ }^{\circledR}$ allows to obtain substantial energy savings leading to DPPs always below 5 years. The highest payback is associated with the kit coupled to the $20 \mathrm{~kW}$ RU (4 years and 10 months), while the lowest to the kit coupled to the $300 \mathrm{~kW}$ RU (1 year and 6 months). As a result, the integration of the kit allows a net saving at the end of the life cycle of about $14,000 €, 91,000 €$, and $273,000 €$, in the $20 \mathrm{~kW}, 100 \mathrm{~kW}$, and $300 \mathrm{~kW}$ coupled systems, respectively.

As for the WC scenarios, in this case the integration of the kit still allows defining acceptable DPPs (below 10 years) when the 100 and the $300 \mathrm{~kW}$ RU is taken into account, i.e. about 7 and 5 years, respectively. However, it is higher than 10 years for the $20 \mathrm{~kW}$ RU configuration. As a result, the integration of the kit allows a net saving at the end of the life cycle of about $8000 €$ and $41,000 €$, in 
Table 7

Summary of the LCC analysis when a Turboalgor kit ${ }^{\circledR}$ is coupled to a 20,100 and $300 \mathrm{~kW}$ refrigeration unit (RU).

\begin{tabular}{|c|c|c|c|c|c|}
\hline Type of costs & & Scenario & $20 \mathrm{~kW}$ RU & $100 \mathrm{~kW}$ RU & $300 \mathrm{~kW}$ RU \\
\hline \multirow[t]{6}{*}{ Investment costs } & Full Turboalgor kit ${ }^{\circledR}$ purchase cost & $\mathrm{BC}$ & $7000 €$ & $31,000 €$ & $53,000 €$ \\
\hline & & WC & $5000 €$ & $15,000 €$ & $37,000 €$ \\
\hline & Consumables for installation & $\mathrm{BC}$ & $3000 €$ & $3000 €$ & $3000 €$ \\
\hline & & WC & $3000 €$ & $3000 €$ & $3000 €$ \\
\hline & Installation at costumer site & $\mathrm{BC}$ & $1500 €$ & $1500 €$ & $1500 €$ \\
\hline & & WC & $1500 €$ & $1500 €$ & $1500 €$ \\
\hline \multirow[t]{2}{*}{$\mathrm{OM} \& \mathrm{R}$ costs } & & $\mathrm{BC}$ & $659 €$ & $2918 €$ & $4990 €$ \\
\hline & & WC & $471 €$ & $1412 €$ & $3483 €$ \\
\hline \multirow[t]{2}{*}{ Energy costs } & & $\mathrm{BC}$ & $1274 €$ & $1274 €$ & $1274 €$ \\
\hline & & WC & $1274 €$ & $1274 €$ & $1274 €$ \\
\hline \multirow[t]{2}{*}{ Disposal costs } & & $\mathrm{BC}$ & $63 €$ & $278 €$ & $474 €$ \\
\hline & & WC & $45 €$ & $134 €$ & $331 €$ \\
\hline \multirow[t]{2}{*}{ LCC } & & BC & $13,496 €$ & $39,970 €$ & $64,238 €$ \\
\hline & & WC & $11,290 €$ & $22,320 €$ & $46,589 €$ \\
\hline
\end{tabular}
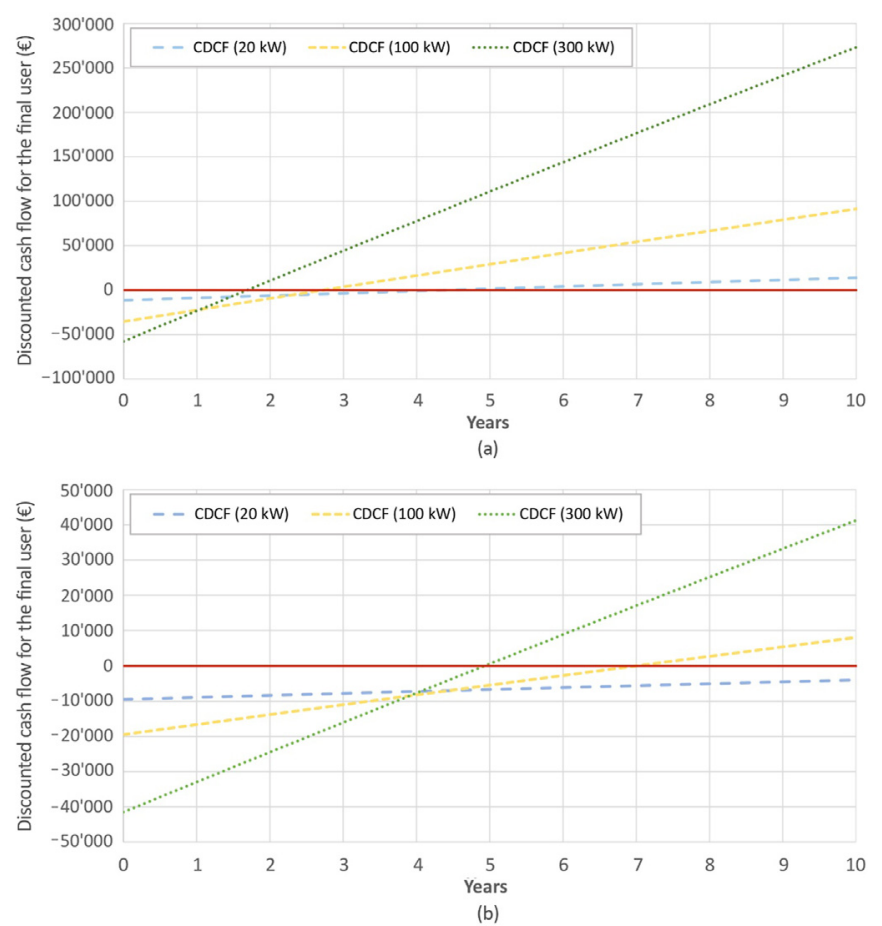

Fig. 15. LCC threshold and cumulate discounted cash flow in time for (a) the BC and (b) WC scenario, considering the three different powers of the refrigeration units, i.e. 20 , 100 and $300 \mathrm{~kW}$.

the $100 \mathrm{~kW}$ and $300 \mathrm{~kW}$ coupled systems, respectively.

\subsection{Discounted payback period: the role of operating time and energy cost}

In this section, the effect of different operating times and energy prices on the final DPP was investigated. Five different operating times, i.e. $3000,3500,4000,4500$, and $5000 \mathrm{~h}$ per year, and two different energy prices, i.e. 0.14 and $0.16 € / \mathrm{kWh}$, were taken into account. Results from these calculations are presented in Table 8. As can be seen, all the configurations, apart from the $20 \mathrm{~kW}$ WC, generally respect the limit DPP of 10 years, even when the extremely low operating time of $3000 \mathrm{~h}$ per year is considered. Both operating time and energy price have a significant effect on the calculated payback. In particular, a change from 4000 to 4500 operating h per year allows to significantly reduce the DPP in all WC configurations. The kit coupled to a $100 \mathrm{~kW} \mathrm{RU}$, for example, reduces its DPP by 11 and 10 months when the energy price of 0.14 $€ / \mathrm{kWh}$ and $0.16 € / \mathrm{kWh}$ is considered.

Concerning the $\mathrm{BC}$ scenario, in this case, using the kit for about $5000 \mathrm{~h}$ per years allows to always reduce the DPP below 4 years, even reaching 1 year when the higher energy price $(0.16 € / \mathrm{kWh})$ and power of the RU ( $300 \mathrm{~kW})$ are taken into account. As for the WC, in this case 5000 operating h per year result in a DPP of about 6 years when the kit is coupled to a $100 \mathrm{~kW}$ RU, and of about 4 years when it is coupled to a $300 \mathrm{~kW}$ RU.

From these results, it is evident that the selected parameters represent the main drivers for the economic assessment of this kind of systems. Therefore, their effect should be carefully assessed to properly evaluate the feasibility of their integration in an existing refrigeration unit.

\section{Conclusions and future prospects}

In this study, a combined environmental and economic analysis was used to investigate the potential of an optimisation kit for industrial refrigeration units: The Turboalgor kit ${ }^{\circledR}$ The LCA was evaluated using real data from the manufacturing company (Turboalgor S.r.l.). Ecoinvent v3.5 database was used to obtain the environmental impacts. Two different methodologies were applied: ReCiPe (End-Point) and IPCC 2013 (GWP). An LCC analysis was also developed, based on the same functional unit and system boundaries of the LCA, considering the product buyer as the main stakeholder of the analysis. In both cases, two different scenarios, i.e. Best-Case (BC) and Worst-Case (WC) scenario, differing in terms of main operating temperature and, consequently, final energy savings were evaluated, considering three refrigeration units characterised by an electrical consumption of $20 \mathrm{~kW}, 100 \mathrm{~kW}$, and $300 \mathrm{~kW}$.

According to the LCA results, the stage with the highest impact to the environment is the cradle to gate, i.e. from raw materials extraction to raw materials distribution to converters, up to their transformation into a semi-manufactured product, and distribution to the final product producer. In detail, the damage to human health is the highest category in impact points with 488 i.p. Indeed, the midpoint category toxicity has so far the highest impact with 244.43 i.p. A large quantity of materials and energy is consumed at this stage, which is translated to a higher quantity of emissions and impacts on the environment. Therefore, a future optimisation procedure could regard the use of materials with a lower impact on the environment, such as recycled materials, for the manufacturing of the Turboalgor kit ${ }^{\circledR}$.

Results from the LCC showed that the investment costs represent the highest impact for the final user in terms of present value, 
Table 8

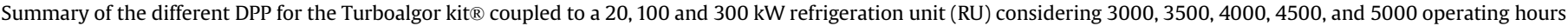
during the year and two different energy prizes ( 0.14 and $0.16 € / \mathrm{kWh}$ ).

\begin{tabular}{|c|c|c|c|c|c|c|c|c|c|c|c|c|c|}
\hline \multirow[b]{2}{*}{ Scenario } & & \multicolumn{12}{|c|}{$\mathrm{DPP}(\mathrm{m}=$ months $)$} \\
\hline & & \multicolumn{6}{|l|}{$\mathrm{BC}$} & \multicolumn{6}{|l|}{ WC } \\
\hline Size & & \multicolumn{2}{|c|}{$20 \mathrm{~kW}$} & \multicolumn{2}{|c|}{$100 \mathrm{~kW}$} & \multicolumn{2}{|c|}{$300 \mathrm{~kW}$} & \multicolumn{2}{|l|}{$20 \mathrm{~kW}$} & \multicolumn{2}{|c|}{$100 \mathrm{~kW}$} & \multicolumn{2}{|c|}{$300 \mathrm{~kW}$} \\
\hline Energy cost $(€ / \mathrm{kWh})$ & & 0.14 & 0.16 & 0.14 & 0.16 & 0.14 & 0.16 & 0.14 & 0.16 & 0.14 & 0.16 & 0.14 & 0.16 \\
\hline \multirow[t]{5}{*}{ Operating hours per year } & 3000 & $79 \mathrm{~m}$ & $72 \mathrm{~m}$ & $46 \mathrm{~m}$ & $41 \mathrm{~m}$ & $24 \mathrm{~m}$ & $21 \mathrm{~m}$ & $420 \mathrm{~m}$ & $389 \mathrm{~m}$ & $127 \mathrm{~m}$ & $117 \mathrm{~m}$ & $86 \mathrm{~m}$ & $78 \mathrm{~m}$ \\
\hline & 3500 & $62 \mathrm{~m}$ & $61 \mathrm{~m}$ & $39 \mathrm{~m}$ & $35 \mathrm{~m}$ & $21 \mathrm{~m}$ & $18 \mathrm{~m}$ & $351 \mathrm{~m}$ & $326 \mathrm{~m}$ & $108 \mathrm{~m}$ & $99 \mathrm{~m}$ & $73 \mathrm{~m}$ & $66 \mathrm{~m}$ \\
\hline & 4000 & $58 \mathrm{~m}$ & $53 \mathrm{~m}$ & $34 \mathrm{~m}$ & $30 \mathrm{~m}$ & $18 \mathrm{~m}$ & $15 \mathrm{~m}$ & $302 \mathrm{~m}$ & $280 \mathrm{~m}$ & 93 m & $85 \mathrm{~m}$ & $63 \mathrm{~m}$ & $57 \mathrm{~m}$ \\
\hline & 4500 & $52 \mathrm{~m}$ & $47 \mathrm{~m}$ & $30 \mathrm{~m}$ & $27 \mathrm{~m}$ & $16 \mathrm{~m}$ & $13 \mathrm{~m}$ & $264 \mathrm{~m}$ & $245 \mathrm{~m}$ & $82 \mathrm{~m}$ & $75 \mathrm{~m}$ & $56 \mathrm{~m}$ & $51 \mathrm{~m}$ \\
\hline & 5000 & $46 \mathrm{~m}$ & $42 \mathrm{~m}$ & $27 \mathrm{~m}$ & $24 \mathrm{~m}$ & $14 \mathrm{~m}$ & $12 \mathrm{~m}$ & $235 \mathrm{~m}$ & $218 \mathrm{~m}$ & $74 \mathrm{~m}$ & $67 \mathrm{~m}$ & $50 \mathrm{~m}$ & $45 \mathrm{~m}$ \\
\hline
\end{tabular}

with an average of $88 \%$ and $87 \%$ in the BC and WC scenarios, respectively. The investigation of the economic discounted payback allowed to verify that the Turboalgor kit $\AA$ is always convenient in the best-case (BC), where the initial investment is recovered after 4 years and 10 months at the latest (when a $20 \mathrm{~kW}$ RU is considered), and energy savings up to $273,000 €$ are found (in the $300 \mathrm{~kW} \mathrm{RU}$ ). In the worst-case, the only configuration with a discounted payback period higher than 10 years is the one associated with the $20 \mathrm{~kW}$ RU. However, the integration of the kit in the $100 \mathrm{~kW}$ and $300 \mathrm{~kW}$ RU allows to obtain convenient DPPs, i.e. 8 years and 4 years and a half, respectively. As a result, in these last configurations a net saving of about $8000 €$ and $41,000 €$, can be found at the end of the life cycle, respectively. In general, operating time and energy cost represent the key features that should be taken into account when investigating the economic feasibility of the kit integration in an existing RU. All this considered, the proper selection of these parameters would be crucial for optimising the functioning of the kit and thus significantly reducing the DPP of each configuration. In general, the integration of the kit seems particularly promising in medium-large refrigeration units characterised by 4000 operating hours per year.

Future studies will focus on optimising the overall production process of the Turboalgor kit ${ }^{\circledR}$, with the aim of reducing its environmental impact during the cradle to gate stage, particularly, considering the integration of lower embodied energy semimanufactured components.

\section{CRediT authorship contribution statement}

Jaume Gasia: Conceptualization, Methodology, Software, Validation, Formal analysis, Investigation, Data curation, Writing review \& editing, Visualization. Claudia Fabiani: Conceptualization, Methodology, Formal analysis, Investigation, Data curation,
Writing - original draft, Visualization. Marta Chàfer: Conceptualization, Methodology, Formal analysis, Investigation, Data curation, Writing - original draft, Visualization. Anna Laura Pisello: Validation, Project administration. Agnese Manni: Validation, Project administration. Maurizio Ascani: Conceptualization, Methodology, Formal analysis, Resources, Writing - review \& editing, Supervision, Project administration, Funding acquisition. Luisa F. Cabeza: Conceptualization, Methodology, Formal analysis, Resources, Data curation, Writing - review \& editing, Supervision, Project administration, Funding acquisition.

\section{Declaration of competing interest}

The authors declare that they have no known competing financial interests or personal relationships that could have appeared to influence the work reported in this paper.

\section{Acknowledgements}

The authors from the University of Lleida would like to thank the Catalan Government for the quality accreditation given to their research group GREiA (2017 SGR 1537). GREiA is a certified agent TECNIO in the category of technology developers from the Government of Catalonia. This work is partially supported by ICREA under the ICREA Academia programme. Jaume Gasia would like to thank the Departament d'Universitats, Recerca i Societat de la Informació de la Generalitat de Catalunya for his research fellowship (2017 FI_B1 00092).

\section{Appendix}

\begin{tabular}{|c|c|c|c|c|c|c|c|c|}
\hline \multirow[t]{2}{*}{ C } & \multirow[t]{2}{*}{ Subcomponent } & \multicolumn{2}{|l|}{$\mathrm{Q}$} & \multicolumn{3}{|l|}{ Material } & \multicolumn{2}{|c|}{ Summary } \\
\hline & & V & $\mathrm{U}$ & Name & $\mathrm{V}$ & $\mathrm{U}$ & V & $\mathrm{U}$ \\
\hline \multirow[t]{8}{*}{ Central body } & Casing & 1 & $\mathrm{u}$ & AISI 304 SS & 84.900 & $\mathrm{~kg} / \mathrm{u}$ & 84.900 & $\mathrm{~kg}$ \\
\hline & Casing (paint color) & 1 & $\mathrm{u}$ & Powder coating & 10.890 & $\mathrm{~m}^{2}$ & 1.360 & $\mathrm{~kg}$ \\
\hline & Machine screw & 10 & $\mathrm{u}$ & Stainless steel & 0.010 & $\mathrm{~kg} / \mathrm{u}$ & 0.100 & $\mathrm{~kg}$ \\
\hline & Flat washer & 10 & $\mathrm{u}$ & Stainless steel & 0.001 & $\mathrm{~kg} / \mathrm{u}$ & 0.010 & $\mathrm{~kg}$ \\
\hline & Window (Glass) & 1 & $\mathrm{u}$ & Glass & 0.010 & $\mathrm{~kg} / \mathrm{u}$ & 0.010 & $\mathrm{~kg}$ \\
\hline & Window (Protection) & 1 & $\mathrm{u}$ & Polyethylene (Rigid) & 0.014 & $\mathrm{~kg} / \mathrm{u}$ & 0.014 & $\mathrm{~kg}$ \\
\hline & Window (Machine Screw) & 4 & $\mathrm{u}$ & Stainless steel & 0.010 & $\mathrm{~kg} / \mathrm{u}$ & 0.040 & $\mathrm{~kg}$ \\
\hline & Door tape & 1 & $\mathrm{u}$ & Polyurethane (Flexible) & 0.300 & $\mathrm{~kg} / \mathrm{u}$ & 0.300 & $\mathrm{~kg}$ \\
\hline \multirow[t]{6}{*}{ Top cabinet } & Casing & 1 & $\mathrm{u}$ & AISI 304 SS & 18.300 & $\mathrm{~kg} / \mathrm{u}$ & 18.300 & $\mathrm{~kg}$ \\
\hline & Casing (paint color) & 1 & $\mathrm{u}$ & Powder coating & 3.050 & $\mathrm{~m}^{2}$ & 0.380 & $\mathrm{~kg}$ \\
\hline & HEX screw & 10 & $\mathrm{u}$ & Stainless steel & 0.010 & $\mathrm{~kg} / \mathrm{u}$ & 0.100 & $\mathrm{~kg}$ \\
\hline & Flat washer & 10 & $\mathrm{u}$ & Stainless steel & 0.001 & $\mathrm{~kg} / \mathrm{u}$ & 0.010 & $\mathrm{~kg}$ \\
\hline & Internal plate & 1 & $\mathrm{u}$ & Stainless steel & 1.800 & $\mathrm{~kg} / \mathrm{u}$ & 1.800 & $\mathrm{~kg}$ \\
\hline & Analogic display & 2 & $\mathrm{u}$ & N.A. & 0.100 & $\mathrm{~kg} / \mathrm{u}$ & 0.200 & $\mathrm{~kg}$ \\
\hline
\end{tabular}


(continued)

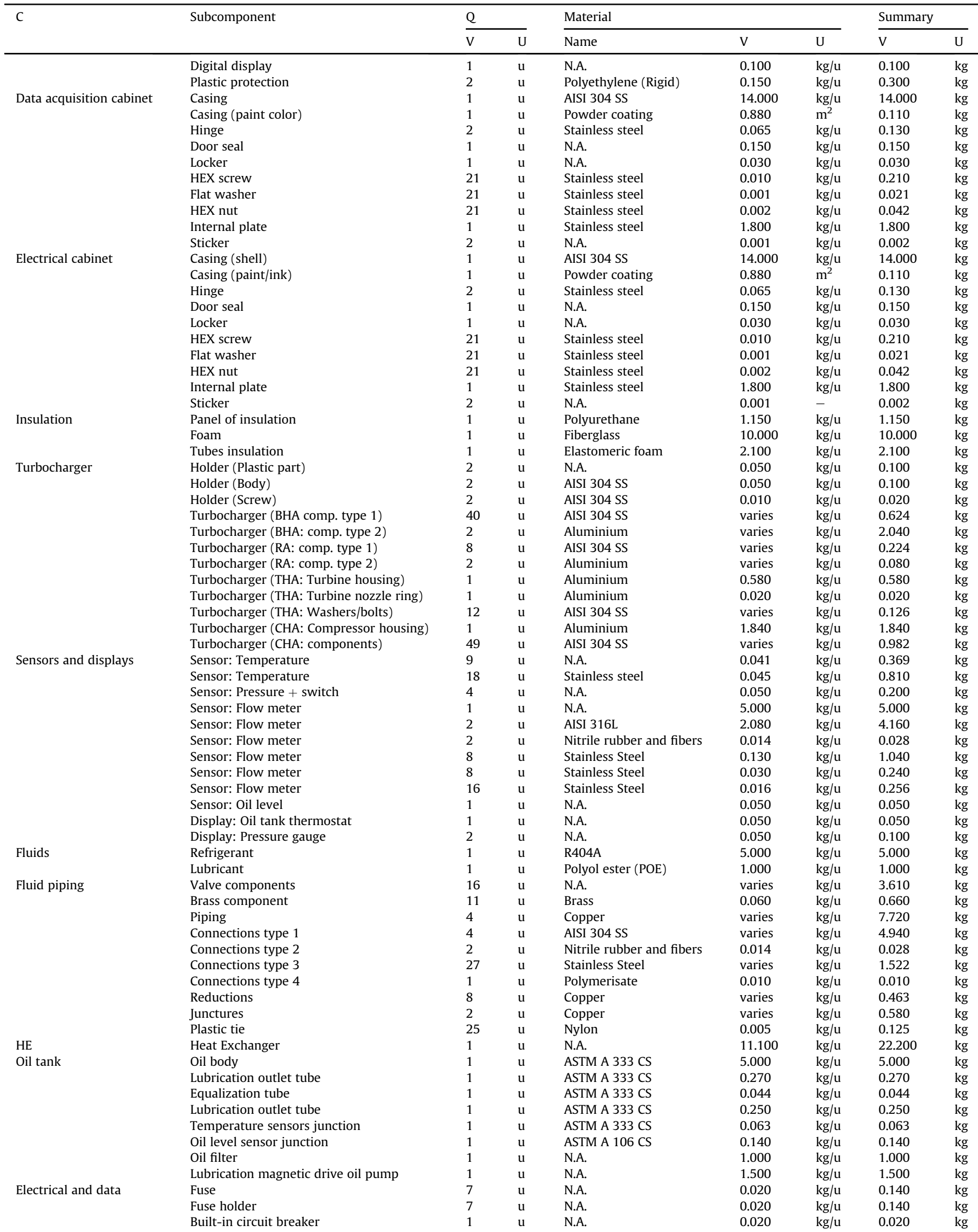

(continued on next page) 


\begin{tabular}{|c|c|c|c|c|c|c|c|c|}
\hline \multirow[t]{2}{*}{$\mathrm{C}$} & \multirow[t]{2}{*}{ Subcomponent } & \multicolumn{2}{|l|}{ Q } & \multicolumn{3}{|c|}{ Material } & \multicolumn{2}{|c|}{ Summary } \\
\hline & & V & $\mathrm{U}$ & Name & V & $\mathrm{U}$ & V & $\mathrm{U}$ \\
\hline & Terminal cover & 1 & $\mathrm{u}$ & N.A. & 0.020 & $\mathrm{~kg} / \mathrm{u}$ & 0.020 & $\mathrm{~kg}$ \\
\hline & Connectors & 2 & $\mathrm{u}$ & N.A. & 0.020 & $\mathrm{~kg} / \mathrm{u}$ & 0.040 & $\mathrm{~kg}$ \\
\hline & Extension shaft & 1 & $\mathrm{u}$ & N.A. & 0.020 & $\mathrm{~kg} / \mathrm{u}$ & 0.020 & $\mathrm{~kg}$ \\
\hline & Integrated filter & 1 & $\mathrm{u}$ & N.A. & 0.020 & $\mathrm{~kg} / \mathrm{u}$ & 0.020 & $\mathrm{~kg}$ \\
\hline & Multifunctional timer & 1 & $\mathrm{u}$ & N.A. & 0.020 & $\mathrm{~kg} / \mathrm{u}$ & 0.020 & $\mathrm{~kg}$ \\
\hline & Green LED & 2 & $\mathrm{u}$ & N.A. & 0.020 & $\mathrm{~kg} / \mathrm{u}$ & 0.040 & $\mathrm{~kg}$ \\
\hline & Trigger and relays & 5 & $\mathrm{u}$ & N.A. & 0.020 & $\mathrm{~kg} / \mathrm{u}$ & 0.100 & $\mathrm{~kg}$ \\
\hline & Amperimetric transformer & 3 & $\mathrm{u}$ & N.A. & 0.100 & $\mathrm{~kg} / \mathrm{u}$ & 0.300 & $\mathrm{~kg}$ \\
\hline & Power supply unit & 1 & $\mathrm{u}$ & N.A. & 0.100 & $\mathrm{~kg} / \mathrm{u}$ & 0.100 & $\mathrm{~kg}$ \\
\hline & PLC Smart Module & 1 & $\mathrm{u}$ & N.A. & 0.050 & $\mathrm{~kg} / \mathrm{u}$ & 0.050 & $\mathrm{~kg}$ \\
\hline & Plug (component) & 13 & $\mathrm{u}$ & N.A. & 0.100 & $\mathrm{~kg} / \mathrm{u}$ & 1.300 & $\mathrm{~kg}$ \\
\hline & Plug (Screw) & 52 & $\mathrm{u}$ & N.A. & 0.005 & $\mathrm{~kg} / \mathrm{u}$ & 0.260 & $\mathrm{~kg}$ \\
\hline & Ferrite plastic cover & 2 & $\mathrm{u}$ & N.A. & 0.020 & $\mathrm{~kg} / \mathrm{u}$ & 0.040 & $\mathrm{~kg}$ \\
\hline & Energy analyser & 1 & $\mathrm{u}$ & N.A. & 0.100 & $\mathrm{~kg} / \mathrm{u}$ & 0.100 & $\mathrm{~kg}$ \\
\hline & Data acquisition module & 1 & $\mathrm{u}$ & N.A. & 0.100 & $\mathrm{~kg} / \mathrm{u}$ & 0.100 & $\mathrm{~kg}$ \\
\hline & Antenna (wifi and Gu@rdian EVO) & 2 & $\mathrm{u}$ & N.A. & 0.100 & $\mathrm{~kg} / \mathrm{u}$ & 0.200 & $\mathrm{~kg}$ \\
\hline & Module gu@rdian EVO & 1 & $\mathrm{u}$ & N.A. & 0.100 & $\mathrm{~kg} / \mathrm{u}$ & 0.100 & $\mathrm{~kg}$ \\
\hline & Electric cable & 1 & $\mathrm{u}$ & N.A. & 10.000 & $\mathrm{~m}$ & 10.000 & $\mathrm{~m}$ \\
\hline & Data cable & 1 & $\mathrm{u}$ & N.A. & 30.000 & $\mathrm{~m}$ & 30.000 & $\mathrm{~m}$ \\
\hline
\end{tabular}

Life cycle inventory (LCI): Summary ( $C=$ component, $Q=$ quantity, $V=$ value, $\mathrm{U}=$ unit, $\mathrm{BHA}=$ Bearing Housing Assembly, $\mathrm{RA}=$ Rotor Assembly, THA = Turbine Housing Assembly, $\mathrm{CHA}=$ Compressor Housing Assembly, $\mathrm{HE}=$ Heat Exchanger).

\section{References}

Ascani, M., 2012. Refrigerating Device and Method for Circulating a Refrigerating Fluid Associated with it. EP2147265B1.

Asdrubali, F., Pisello, A.L., D’Alessandro, F., Bianchi, F., Fabiani, C., Cornicchia, M., Rotili, A., 2016. Experimental and numerical characterisation of innovative cardboard based panels: thermal and acoustic performance analysis and life cycle assessment. Build. Environ. 95, 145-159. https://doi.org/10.1016/ j.buildenv.2015.09.003.

Auer, J., Bey, N., Schäfer, J.-M., 2017. Combined Life Cycle Assessment and Life Cycle Costing in the Eco-Care-Matrix: a case study on the performance of a modernised manufacturing system for glass containers. J. Clean. Prod. 141, 99-109. https://doi.org/10.1016/j.jclepro.2016.08.096.

Baxter, J., 2019. Systematic environmental assessment of end-of-life pathways for domestic refrigerators. J. Clean. Prod. 208, 612-620. https://doi.org/10.1016/ j.jclepro.2018.10.173.

Brom, A.E., Belova, O.V., Sissinio, A., 2016. Life-cycle costs for energy equipment: FMECA \& life-cycle costing models as "decision making" tools for cost reduction during the whole equipment life. Procedia Eng. 152, 173-176. https://doi.org/ 10.1016/j.proeng.2016.07.687.

Bruijn, H., van Duin, R., Huijbregts, AJ., M, 2002. Main characteristics of LCA. In: Rosenbaum, M.Z., Hauschild, R.K., Olsen, S.I. (Eds.), Life Cycle Assessment: Theory and Practice. Elsevier. https://doi.org/10.1007/0-306-48055-7_2.

Chàfer, M., Sole-Mauri, F., Solé, A., Boer, D., Cabeza, L.F., 2019. Life cycle assessment (LCA) of a pneumatic municipal waste collection system compared to traditional truck collection. Sensitivity study of the influence of the energy source. J. Clean. Prod. 231, 1122-1135. https://doi.org/10.1016/j.jclepro.2019.05.304.

De Menna, F., Dietershagen, J., Loubiere, M., Vittuari, M., 2018. Life cycle costing of food waste: a review of methodological approaches. Waste Manag. 73, 1-13. https://doi.org/10.1016/j.wasman.2017.12.032.

Dong, Y.H., Ng, S.T., 2014. Comparing the midpoint and endpoint approaches based on ReCiPe - a study of commercial buildings in Hong Kong. Int. J. Life Cycle Assess. 19, 1409-1423. https://doi.org/10.1007/s11367-014-0743-0.

Ekvall, T., Suh, S., Koehler, A., Hellweg, S., Hauschild, M.Z., Finnveden, G., Guinée, J., Heijungs, R., Pennington, D., 2009. Recent developments in life cycle assessment. J. Environ. Manag. 91, 1-21. https://doi.org/10.1016/ j.jenvman.2009.06.018.

Eurostat, 2019a. Labour Cost Index - Recent Trends.

Eurostat, 2019b. Escalation Rates - Recent Trends.

Eurostat, 2019c. Electricity Price Statistics.

Faraca, G., Martinez-Sanchez, V., Astrup, T.F., 2019. Environmental life cycle cost assessment: recycling of hard plastic waste collected at Danish recycling centres. Resour. Conserv. Recycl. 143, 299-309. https://doi.org/10.1016/ j.resconrec.2019.01.014.

Frischknecht, R., Jungbluth, N., Althaus, H.J., Doka, G., Dones, R., Heck, T., Hellweg, S., Hischier, R., Nemecek, T., Rebitzer, G., Spielmann, M., 2005. The ecoinvent database: overview and methodological framework. Int. J. Life Cycle Assess. 10, 3-9. https://doi.org/10.1065/lca2004.10.181.1.

Fuller, S., Petersen, S., 1996. Life-cycle Costing Manual for the Federal Energy Management Program, 1995 Edition. NIST Handb.

Goedkoop, M.J., 2008. Category Indicators at the Midpoint and the Endpoint Level ReCiPe 2008. https://doi.org/10.2307/40184439.

Goedkoop, M.J., Heijungs, R., Huijbregts, M., De Schryver, A., Struijs, J., van Zelm, R., 2013. ReCiPe 2008, A Life Cycle Impact Assessment Method Which Comprises
Harmonised Category Indicators at the Midpoint and the Endpoint Level; First Edition Report I: Characterisation; January 6th 2009 133. http://www.lciarecipe.net.

Guinée, J.B., Heijungs, R., Huppes, G., Zamagni, A., Masoni, P., Buonamici, R., Ekvall, T., Rydberg, T., 2011. Life cycle assessment: past, present, and future. Environ. Sci. Technol. 45, 90-96. https://doi.org/10.1021/es101316v.

Huijbregts, M.A.J., Steinmann, Z.J.N., Elshout, P.M.F., Stam, G., Verones, F., Vieira, M., Zijp, M., Hollander, A., van Zelm, R., 2017. ReCiPe2016: a harmonised life cycle impact assessment method at midpoint and endpoint level. Int. J. Life Cycle Assess. 22, 138-147. https://doi.org/10.1007/s11367-016-1246-y.

Hunkeler, D., Lichtenvort, K., Rebitzer, G., 2008. Environmental Life Cycle Costing, Environmental Life Cycle Costing. https://doi.org/10.1201/9781420054736.

Intergovernmental Panel on Climate Change, 2014. Climate Change 2013 - the Physical Science Basis: Working Group I Contribution to the Fifth Assessment Report of the Intergovernmental Panel on Climate Change. Cambridge University Press, Cambridge. https://doi.org/10.1017/CBO9781107415324.

ISO 14040, 2006a. Gestión ambiental Análisis del ciclo de vida Principios y marco de referencia (ISO 14040:2006).

ISO 14044, 2006b. Gestión ambiental Análisis del ciclo de vida Requisitos y directrices.

ISO 15686-5, 2017. Buildings and Constructed Assets - Service Life Planning - Part 5: Life-Cycle Costing. Geneva, $\mathrm{CH}$.

Klugmann-Radziemska, E., Kuczyńska-Łażewska, A., 2020. The use of recycled semiconductor material in crystalline silicon photovoltaic modules production a life cycle assessment of environmental impacts. Sol. Energy Mater. Sol. Cells 205, 110259. https://doi.org/10.1016/j.solmat.2019.110259.

Li, M.-J., Tao, W.-Q., 2017. Review of methodologies and polices for evaluation of energy efficiency in high energy-consuming industry. Appl. Energy 187, 203-215. https://doi.org/10.1016/j.apenergy.2016.11.039.

Lv, J., Gu, F., Zhang, W., Guo, J., 2019. Life cycle assessment and life cycle costing of sanitary ware manufacturing: a case study in China. J. Clean. Prod. 238, 117938. https://doi.org/10.1016/j.jclepro.2019.117938.

Martínez-Rocamora, A., Solís-Guzmán, J., Marrero, M., 2016. LCA databases focused on construction materials: a review. Renew. Sustain. Energy Rev. 58, 565-573. https://doi.org/10.1016/j.rser.2015.12.243.

Oh, J.-S., Binns, M., Park, S., Kim, J.-K., 2016. Improving the energy efficiency of industrial refrigeration systems. Energy 112, 826-835. https://doi.org/10.1016/ j.energy.2016.06.119.

Rebitzer, G., Ekvall, T., Frischknecht, R., Hunkeler, D., Norris, G., Rydberg, T., Schmidt, W.-P., Suh, S., Weidema, B., W Pennington, D., 2004. Life cycle assessment Part 1: framework, goal and scope definition, inventory analysis, and applications. Environ. Int. 30, 701-720. https://doi.org/10.1016/ j.envint.2003.11.005.

Ristimäki, M., Säynäjoki, A., Heinonen, J., Junnila, S., 2013. Combining life cycle costing and life cycle assessment for an analysis of a new residential district energy system design. Energy 63, 168-179. https://doi.org/10.1016/ j.energy.2013.10.030.

statistica, 2019. Inflation Rate in the European Union and the Euro Area from 2014 to 2024 .

The World Bank, 2019. Indicators.

Visentin, C., da Silva Trentin, A.W., Braun, A.B., Thomé, A., 2019. Life-cycle assessment of environmental and economic impacts of nano-iron synthesis process for application in contaminated site remediation. J. Clean. Prod. 231, 307-319. https://doi.org/10.1016/j.jclepro.2019.05.236. 
Waide, P., Brunner, C.U., 2011. Energy-efficiency policy opportunities for electric motor-driven systems. Cedex, Fr. Int. Energy Agency 132. https://doi.org/ 10.1787/5kgg52gb9gjd-en.

Wernet, G., Bauer, C., Steubing, B., Reinhard, J., Moreno-Ruiz, E., Weidema, B., 2016. The ecoinvent database version 3 (part I): overview and methodology. Int. J. Life Cycle Assess. https://doi.org/10.1007/s11367-016-1087-8.

Xiao, R., Zhang, Y., Liu, X., Yuan, Z., 2015. A life-cycle assessment of household refrigerators in China. J. Clean. Prod. 95, 301-310. https://doi.org/10.1016/ j.jclepro.2015.02.031.
Zhang, W., Gu, F., Dai, F., Gu, X., Yue, F., Bao, B., 2016. Decision framework for feasibility analysis of introducing the steam turbine unit to recover industrial waste heat based on economic and environmental assessments. J. Clean. Prod. 137, 1491-1502. https://doi.org/10.1016/j.jclepro.2016.07.039.

Zhang, W., Guo, J., Gu, F., Gu, X., 2018. Coupling life cycle assessment and life cycle costing as an evaluation tool for developing product service system of high energy-consuming equipment. J. Clean. Prod. 183, 1043-1053. https://doi.org/ 10.1016/j.jclepro.2018.02.146. 